\title{
Chitosan-Encapsulated Nano-selenium Targeting TCF7L2, PPARY, and CAPN10 Genes in Diabetic Rats
}

\author{
Omayma A. R. Abozaid ${ }^{1}$ (D) . Sawsan M. El-Sonbaty ${ }^{2}$ (D) - Neama M. A. Hamam ${ }^{1} \cdot$ Moustafa A. Farrag $^{3}$ (D) \\ Ahmad S. Kodous ${ }^{3}$ iD
}

Received: 1 January 2022 / Accepted: 26 January 2022 / Published online: 2 March 2022

(C) The Author(s) 2022

\begin{abstract}
This study investigates the antidiabetic and antioxidant potential of chitosan-encapsulated selenium nanoparticles in streptozotocin-induced diabetic model. Glibenclamide was used as a reference antidiabetic drug. Forty-eight adult male Wistar rats were used along the study and divided equally into 6 groups of (I) normal control, (II) chitosan-encapsulated selenium nanoparticles (CTS-SeNPs), (III) glibenclamide, (IV) streptozotocin (STZ), (V) STZ+CTS-SeNPs, and (VI) STZ+ Glib. The animals were sacrificed on the 35th day of the experiment. Serum glucose, insulin, IGF-1, ALT, AST, CK-MB, oxidative stress, lipid profile, and inflammatory parameters were subsequently assessed. Also, the expression level of TCF7L2, CAPN10, and PPAR- $\gamma$ genes were evaluated using qPCR. In addition, histopathological studies on pancreatic tissue were carried out. The results revealed that STZ induced both diabetes and oxidative stress in normal rats, manifested by the significant changes in the studied parameters and in the physical structure of pancreatic tissue. Oral administration of CTSSeNPs or Glib results in a significant amelioration of the levels of serum fasting blood glucose, insulin, IGF-1, AST, ATL, and CK-MB as compared with STZ-induced diabetic rats. CTS-SeNPs and Glib diminished the level of lipid peroxidation, increased total antioxidant capacity level, as well as possessed strong inhibition against serum $\alpha$-amylase and $\alpha$-glucosidase activities. Diabetic animals received CTS-SeNPs, or Glib demonstrated a significant $(p<0.05)$ decrease in the expression level of TCF7L2 and CAPN10 genes with a significant increase in the expression level of PPAR- $\gamma$ gene, compared to STZ group. The above findings clarify the promising antidiabetic and antioxidant effect of CTS-SeNPs, recommending its inclusion in the currently used protocols for the treatment of diabetes and in the prevention of its related complications.
\end{abstract}

Keywords Diabetes mellitus $\cdot$ Selenium nanoparticles $\cdot$ Chitosan $\cdot$ Glibenclamide $\cdot$ TCF7L2 $\cdot$ CAPN10 $\cdot$ PPAR- $\gamma$

Ahmad S. Kodous

ahmadkmp11@gmail.com; ahmad.kodous@eaea.org.eg

Omayma A. R. Abozaid

omayma.abozaid@fvtm.bu.edu.eg

Sawsan M. El-Sonbaty

Sawsan.sonbaty@eaea.org.eg

Neama M. A. Hamam

neamamostafa@yahoo.com

Moustafa A. Farrag

mostafafarrag27@yahoo.com

1 Clinical Biochemistry Department, Faculty of Veterinary Medicine, Benha University, Moshtohor, Egypt

2 Radiation Microbiology Department, National Center for Radiation Research and Technology, Egyptian Atomic Energy Authority, Cairo, Egypt

3 Radiation Biology Department, National Center for Radiation Research and Technology, Egyptian Atomic Energy Authority, Cairo, Egypt

\section{Introduction}

Diabetes mellitus (DM) is a growing epidemic that affects quality of life. It is one of the leading causes of morbidity and mortality throughout the world [1]. Diabetes mellitus (DM) is a metabolic disease characterized by chronic hyperglycemia, as well as glucose, adipose tissue, and protein metabolism disorders caused by impaired insulin production by pancreatic $\beta$-cells and/or insulin resistance by peripheral tissues [2]. In 2019, about $9.3 \%$ of adults aged 20-79 are living with DM in the Middle East and North Africa Region. Egypt is the nation with the ninth-largest population of diabetics in the world. According to the International Diabetes Federation (IDF), there were 8.2 million (14.5\%) diabetic patients in Egypt in 2017. It is expected that this number will bounce up to 13.1 million by 2035 [3-5]. Diabetes mellitus is associated with several macro-vascular 
and microvascular complications that ultimately impact the overall patient's survival. It has been reported that oxidative stress is a known pathway in the pathogenesis of diabetic complications [6]. Hyperglycemic-induced oxidative stress is thought to enhance proinflammatory protein levels, with infiltrated macrophages secreting inflammatory cytokines, resulting in local and systemic inflammation [7]. Furthermore, several studies have found elevated levels of IL6 and TNF- $\alpha$ in patients with insulin resistance and clinically diagnosed diabetes. Chronic hyperglycemia is an important factor that may contribute to inflammation [8]. Alongside with oxidative stress and hyperglycemia, hyperlipidemia has been prescribed as a causative factor for augmenting morbidity and mortality in diabetic individuals [9].

Finding efficient multifunctional therapeutic agents that act more broadly to repress diabetic complications may offer a greater advantage. One of the most promising tools in DM management is the use of natural health products. Several trace metals, including chromium, selenium, vanadium, molybdenum, and magnesium, have been known to have hypoglycemic activity, possibly due to insulin-mimetic effects $[10,11]$. Thus, dietary supplementation with wellstudied trace metals could be a promising treatment option for DM patients, acting in addition to approved pharmacological therapies. Currently, several nanoparticles are used as alternative therapies due to their multifunctional biological activities, which treat diabetic complications and combat inflammation. Interestingly, selenium is an essential antioxidant and anti-inflammatory micronutrient that can prevent ROS production by improving the activity of GPx and selenoproteins [12]. Additionally, Se-NPs have unique biological advantages with excellent bioavailability and a sevenfold lower toxicity than sodium selenite [13]. Besides its unique abilities, for more stability of Se-NPs in solutions, stabilizing agents such as polysaccharides are added; the active hydroxyl groups in polysaccharides can improve the bioavailability and biological activity, producing a synergistic effect between Se-NPs and polysaccharides [14].

Chitosan is a naturally occurring, linear polysaccharide that is regarded as the second most important renewable biomaterial after cellulose in terms of utilization and distribution [15].

Due to their unique biological properties, chitosan and its derivative biomaterials have piqued the interest of researchers in the biomedical field. Chitosan's non-toxicity, biodegradability, biocompatibility, and immunoenhancing, antitumoral, antibacterial, and antimicrobial activity are among its most notable medical properties [16]. Chitosan-based nanoparticles with high permeability and retention can also inhibit tumor cell growth by inducing apoptosis. Particles as small as 100-200 $\mathrm{nm}$ can be taken up by receptor-mediated endocytosis, whereas larger particles must be taken up by phagocytosis [17].
Hence, the objective of this study is to investigate the antidiabetic potential of chitosan-encapsulated selenium nanoparticles as well as explore its antioxidant and cardioprotective activity in streptozotocin-induced diabetic rats.

\section{Materials and Methods}

\section{Chemicals}

Streptozotocin (STZ), sodium selenite $\left(\mathrm{Na}_{2} \mathrm{SeO}_{3}\right)$, acetic acid and chitosan-extracted from shrimp shells were purchased from Sigma Chemical, St. Louis, USA. The commercial pharmaceutical drug glibenclamide (Glib) is of dietary supplement tablets (Dianil® 5 mg, Sanofi, Egypt).

\section{Synthesis Chitosan-Selenium Nanoparticles (CTS-SeNPs)}

Biosynthesis of CTS-SeNPs was processed by a method of Hien et al. [15]. CTS solution ( $1 \% \mathrm{w} / \mathrm{v})$ was dissolved in a diluted acetic acid solution ( $3 \% \mathrm{w} / \mathrm{v})$. After dissolution, CS solution was stored in the dark $\left(24.0 \pm 2{ }^{\circ} \mathrm{C}\right)$ overnight to ensure the homogeneity. Additionally, $1 \mathrm{mM}$ of selenium dioxide solution was mixed with CS solution (v/v). Finally, the mixture was stirred at room temperature for $20 \mathrm{~min}$ and then exposed to a dose of $20 \mathrm{kGy}$, with the dose rate of $2.5 \mathrm{kGy} / \mathrm{h}$. The formation of Se NPs was indicted by the appearance of red-colored solution.

\section{Characterization of CTS-SeNPs}

\section{Transmission Electron Microscopy (TEM)}

Synthesized CTS-SeNPs was characterized by using transmission electron microscope (TEM) of JOEL JEM-2100, microscope with an accelerating voltage of $200 \mathrm{kV}$, attached to Gatan Digital Camera, Model Erlangshen ES500.

\section{Ultraviolet-Visible Absorption}

Spectrum absorbance of CTs-Se NPs was scanned at range of 200-600 $\mathrm{nm}$ by ultraviolet-visible (UV-VIS) spectrophotometer using Jenway UV spectrophotometer model 6505.

\section{Dynamic Light Scattering (DLS)}

Sample of CTS-SeNPs was analyzed for size dimensions by DLS Zetasizer (ZS) which was manufactured in Malvern, UK. 


\section{Acute Toxicity Study}

Acute oral toxicity study was performed according to the 423 guidelines (acute toxicity class method) lay down by OECD (Organisation of Economic Cooperation and Development). Healthy male Wistar rats were randomly divided into ten groups with five animals in each group.

A single acute dose of CTS-SeNPs prepared in sterile distilled water was administered orally by gavage at five different concentrations $(2,5,7.5,10$, and $15 \mathrm{mg} / \mathrm{kg} \mathrm{Se})$. Toxicity signs and mortality were observed within 7 days after the treatment. Interestingly, oral administration of SeNPs did not show mortality at any of the concentrations tested.

The arithmetic method of Karber [18] was used for the determination of LD50. LD50 $=\operatorname{LD} 100-\sum(a \times b) / n . n$ is the total number of animal in a group, $a$ the difference between two successive doses of administered extract/substance, $b$ the average number of dead animals in two successive doses, and $L D 100$ lethal dose causing the $100 \%$ death of all test animals.

\section{Induction of Diabetes}

Rats were given free access to water and either a standard pellet diet (APRI animal feed) from Animal Production Research Institute (APRI), Dokki, Giza, Egypt, with carbohydrate, protein, and lipids by $72.1,22.1$, and $5.7 \%$, respectively, and a total caloric value of $3100 \mathrm{kcal} / \mathrm{kg}$, or a high-fat diet (HFD) with carbohydrate, protein, and lipids by $27.5,14.5$, and $58.8 \%$, respectively, and a total caloric value of $4900 \mathrm{kcal} / \mathrm{kg}$. As according to the American Institute of Nutrition [19], corn oil and beef tallow were the fat source in the diet, as well as butter and casein as a protein source in the diet since casein has an acceptable amino acid composition. Casein's main constraint is a lack of sulfur amino acids, notably cystine/cysteine. This deficiency was corrected by supplementing the diet with DL-methionine, which is turned to cysteine in the body [19]. Table 1 shows the composition of the HFD.

Wistar rats were received HFD for 2 weeks followed by single intraperitoneal injection of STZ dissolved in $0.1 \mathrm{M}$ freshly prepared sodium citrate buffer $(\mathrm{pH}=6.5)$ at a dose of $(50 \mathrm{mg} / \mathrm{kg} \mathrm{b.wt})$ [20].

Table 1 Composition of highfat diet

\begin{tabular}{lc}
\hline Ingredients & Diet $(\mathrm{g} / \mathrm{kg})$ \\
\hline Normal pellet diet & 585.4 \\
Butter & 310.9 \\
Casein & 73.2 \\
Mineral mix & 24.6 \\
Vitamin mix & 4.1 \\
DL-methionine & 1.8 \\
\hline
\end{tabular}

Seventy-two hours after induction, blood samples were obtained from the tips of the rat's tail, and the fasting blood glucose levels were determined using OneTouch Ultra glucometer (LifeScan, USA) to confirm diabetes. Rats with fasting blood glucose levels of $\geq 200 \mathrm{mg} / \mathrm{dL}$ were used for the experiment [16].

\section{Experimental Design}

Forty-eight male Wistar rats were obtained from the Nile Pharmaceutical Co., Cairo, Egypt, with body weight 150-200 gm. Rats were housed at the animal house of the National Center for Radiation Research and Technology (NCRRT) and the Egyptian Atomic Energy Authority (EAEA), Cairo, Egypt. Rats were randomly divided into 6 groups of 8 animals in each group (Fig. 1).

Body weights were recorded along the experimental period at $7,14,21,28$, and 35 days of the experimental time. After 35 days, the animals were fasted for $12 \mathrm{~h}$, anaesthetized using ketamine $(24 \mathrm{mg} / \mathrm{kg}$ b.wt. intramuscular injection), and sacrificed by decapitation. Blood samples for serum were collected. Additionally, pancreas was excised and divided into two parts as follows: 1st was used for the determination of gene expression levels of TC7L2, PPAR- $\gamma$, and CAPN10 by real-time PCR. The 2nd was fixed in $10 \%$ neutral formalin overnight, embedded in paraffin, and cut into $4-5-\mu \mathrm{m}$ sections for histological analysis following hematoxylin and eosin staining.

\section{Biochemical Analyses}

\section{Determination of Fasting Blood Glucose}

Blood glucose level was measured via the glucose oxidase method according to Trinder [21] using a glucose assay kit of Spectrum-Diagnostics, Cairo, Egypt.

\section{Determination of Serum Insulin, TNF-a, IL-6, IGF-1, and IL-1 $\beta$}

The serum insulin, TNF- $\alpha$, IL- 6 , IGF- 1 , and IL- $1 \beta$ concentrations were measured by an enzyme-linked immunosorbent assay method using kits from MYBiosource Company according to the manufacturer's instructions.

\section{Determination of the Oxidant and Antioxidant Parameters}

The activity of catalase (CAT) and reduced glutathione (GSH) were determined as described in commercial kits (Randox Laboratories Ltd, Antrim, UK). Total antioxidant capacity (TAC) and malondialdehyde (MDA) concentrations were determined as described in commercial kits (Biodiagnostic Co., Egypt). 


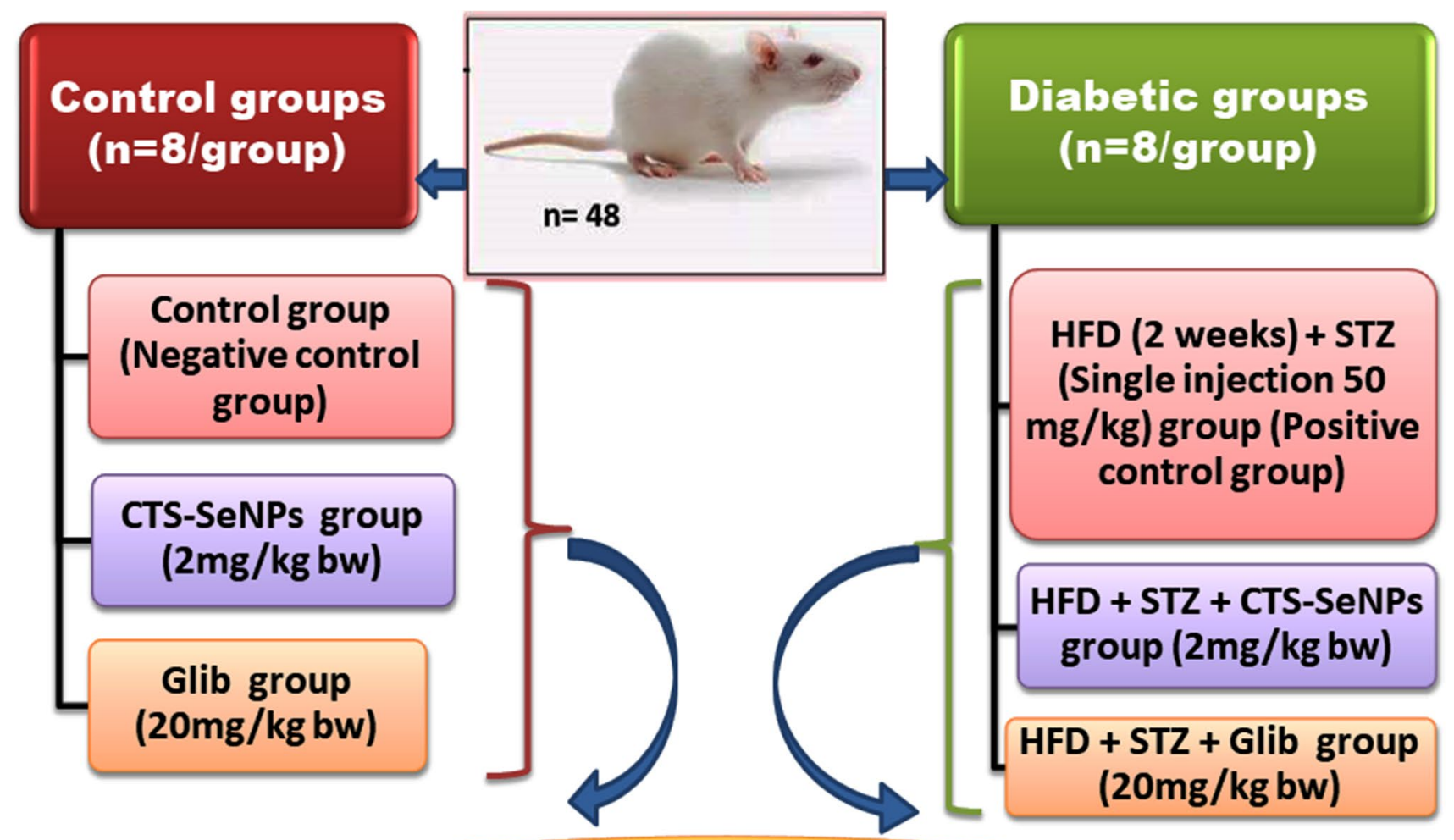

\section{All groups are sacrificed after $\mathbf{3 5}$ days of treatment Blood and pancreatic tissues are isolated Biochemical, molecular and histopathological studies}

Fig. 1 Experimental design. Group (normal control), Group II (CTS-SeNPs): rats were administered with CTS-SeNPs [17]. Group III (Glib): nondiabetic rats were administered with Glib [17]. Group IV (STZ) (diabetic control). Group V (STZ+CTS-SeNPs). Group VI (STZ+ Glib)

\section{Determination of Hepatic and Cardiac Enzymes}

Serum hepatic enzymes alanine transaminase (ALT), aspartate transaminase (AST), alkaline phosphatase (ALP), gamma-glutamyl transferase (GGT), total bilirubin, and albumin were measured by kit methods (Biodiagnostic Co., Egypt). Moreover, serum CK-MB fraction activity was detected using kit of BIOMED diagnostic according to $\mathrm{Wu}$ and Bowers [22].

\section{Determination of a-Amylase and a-Glucosidase Activity in Serum}

The activity of both $\alpha$-amylase and $\alpha$-glucosidase was determined in serum spectrophotometrically using kits of Biodiagnostic Co., Egypt, and Biovision, Egypt, respectively.

\section{Determination of Lipid Profile}

The relative clinical biochemical parameters such as TG, HDL-C, and LDL-C were measured using available diagnostic kits (Biodiagnostic Co., Egypt) following the respective kit specifications.

\section{Molecular Analysis}

Total RNA isolation from pancreatic tissues was performed using RNeasy Plus Minikit (Qiagen, USA) to measure the expression level of the specified genes. cDNA was synthesized by following the protocol provided with the iScript ${ }^{\mathrm{TM}}$ cDNA synthesis kit (Bio-Rad, CA). Real-time PCR was carried out via Power SYBR ${ }^{\circledR}$ Green (Life Technologies, CA) and the Applied Biosystems, 7500 Instrument. The reference gene used was $\beta$-actin, and cDNA samples were run in triplicates. The thermal cycling program used was as follows: heating at $95{ }^{\circ} \mathrm{C}$ for $10 \mathrm{~min}$ during the initial denaturation stage, $95{ }^{\circ} \mathrm{C}$ in the amplification phase for $10 \mathrm{~s}$ which was left to run $40-45$ cycles, $66{ }^{\circ} \mathrm{C}$ for $10 \mathrm{~s}$ in the annealing phase, and finally $72{ }^{\circ} \mathrm{C}$ for $20 \mathrm{~s}$ in the extension phase. The single fluorescence was captured for each capillary to perform signal detection. The cycle threshold (CT) was measured for both target genes. Subsequently, the 
Table 2 Primer sequence of CAPN10, TCF7, PPAR- $\gamma$, and $\beta$-actin

\begin{tabular}{|c|c|}
\hline Gene symbol & Primer sequence \\
\hline CAPN10 & $\begin{array}{l}\text { Forward: 5'- AACCCAGCGAGGTGTGTGTGGCTG } \\
\text { TT-3' } \\
\text { Reverse: 5'GCAGTGTTGCTGTAGGGTGATACG } \\
\text { GATG-3' }\end{array}$ \\
\hline TCF7 & $\begin{array}{l}\text { forward: 5'-GAG TGC GAA ATC CCC AGT TA-3' } \\
\text { reverse: 5'-ATG CAT GGC TTC TTG CTC TT-3' }\end{array}$ \\
\hline PPAR- $\gamma$ & $\begin{array}{l}\text { Forward: 5'-AAGCCATCTTCACGATGCTG-3' } \\
\text { Reverse: 5'-TCAGAGGTCCCTGAACAGTG-3' }\end{array}$ \\
\hline$\beta$-actin & $\begin{array}{l}\text { Forward: 5'-TGTTGTCCCTGTATGCCTCT-3' } \\
\text { Reverse: 3'-TAATGTCACGCACGATTTCC-5' }\end{array}$ \\
\hline
\end{tabular}

relative quantization (RQ) for each sample was calculated using a specific formula to normalize the expression towards the housekeeping gene also to be able to compare it with the control. At first, the $\Delta \mathrm{CT}$ was measured for each sample, in which ${ }^{\Delta} \mathrm{CT}=\mathrm{CT}$ related to the target gene - CT of the housekeeping gene. Secondly, the ${ }^{\Delta \Delta} \mathrm{CT}$ was evaluated for each sample in which ${ }^{\Delta \Delta} \mathrm{CT}={ }^{\Delta} \mathrm{CT}$ related to the experimental sample and $-{ }^{\Delta} \mathrm{CT}$ is for the control. Finally, the RQ was calculated where $R Q=2^{-\Delta \Delta C T}$.

The PCR primers for gene were designed using the NCBI, Primer-Blast program, which were fabricated using Euro fins MWG Operon (Huntsville, AL). Their sequence is indicated in Table 2.

\section{Histopathological Study}

Specimens from pancreas tissue were fixed in $10 \%$ buffered neutral formalin solution, dehydrated, embedded in bee wax paraffin, and then cut to 5- $\mu \mathrm{m}$-thick paraffin sections on glass slides. Specimens were stained with hematoxylin and eosin "H\&E" by routine procedure of Banchroft et al. [23].

\section{Statistical Analysis}

Statistical analyses were performed using IBM, SPSS program (version 22Inc, Chicago, USA). Differences between groups were calculated using one-way analysis of variance (ANOVA) followed by Duncan's test post hoc analysis. All values were expressed as Mean $\pm \mathrm{SD}$, and differences were considered significant at $P<0.05$.

\section{Results}

\section{Characterization of the Synthesized CTS-SeNPs}

Identification of specific characters of the prepared CTSSeNPs such as particle shape and size was investigated via
TEM analysis. CTS-SeNPs showed well-identified spherical shape, with a size around $50-130 \mathrm{~nm}$ as shown in Fig. 2a. The formation of SeNPs was confirmed by changing the color of the solution into red and detection of a max-peak in the visible region at $272.5 \mathrm{~nm}$ characteristic for CTS-SeNPs (Fig. 2b and d). DLS results showed that CTS-SeNPs size is ranged from 39.4 to $265.6 \mathrm{~nm}$ with high percentage of sizes 52.85, 61.2, 82.09, and 95.07 of 14.5, 16.4, 12.9, and 10.6\% respectively (Fig. 2c). FTIR spectrum of CTS-SeNPs (Fig. 2e) shows a strong signal at 3444.24 representing $-\mathrm{OH}$, at 1634.00 representing amid I of proteins, and at 662.75 representing carbon with $-\mathrm{H}$ or $-\mathrm{N}$ which with other weak peak bonds named finger print.

\section{Determination of Acute Toxicity Median Lethal Dose $\left(\mathrm{LD}_{50}\right)$ of CTS-SeNPs in Rats}

Oral administration of different concentrations of the synthesized CTS-SeNPs ranging $2-15 \mathrm{mg} / \mathrm{Se} / \mathrm{kg}$. b.wt did not produce any mortality.

\section{Effect of STZ, CTS-SeNPs, or Glib on Serum Glucose, Insulin, and IGF-1 Levels in Diabetic Rats}

Intraperitoneal injection of STZ to normal animals induced a marked increase in serum glucose level, confirming the diabetogenic effect of STZ, whereas the levels of serum insulin and IGF-1 were significantly decreased $(1.4 \pm 0.19$ and $11.5 \pm 3.5$, respectively) as compared to control group. Remarkably, administration of CTS-SeNPs or Glib to diabetic rats significantly $(p \leq 0.05)$ reduced glucose levels relevant to STZ group. Simultaneously, treating diabetic rats with CTS-SeNPs or Glib significantly $(p \leq 0.05)$ restored the levels of serum insulin and IGF-1 as compared to STZ group. On the other hand, no significant changes were observed in the level of these parameters between normal controls, CTS-SeNPs, or Glib animals (Table 3).

Values are expressed as mean $\pm \mathrm{SD}$ in each group $(n=8)$. Different symbols are significant at $p \leq 0.05$ (Duncan's test).

\section{Effect of STZ, CTS-SeNPs, or Glib on Serum a-Amylase and $a$-Glucosidase Activities}

Analysis of the data of $\alpha$-amylase and $\alpha$-glucosidase activity of diabetic group (STZ) showed a significant $(p \leq 0.05)$ increase in their enzymatic activities $(482.5 \pm 17.4$ and $103.0 \pm 3.3$, respectively) as compared to normal control group. Diabetic rats treated with CTS-SeNPs or Glib revealed a significant decrease in $\alpha$-amylase and $\alpha$-glucosidase activities $(p \leq 0.05)$ relevant to STZ group (Fig. 3). 


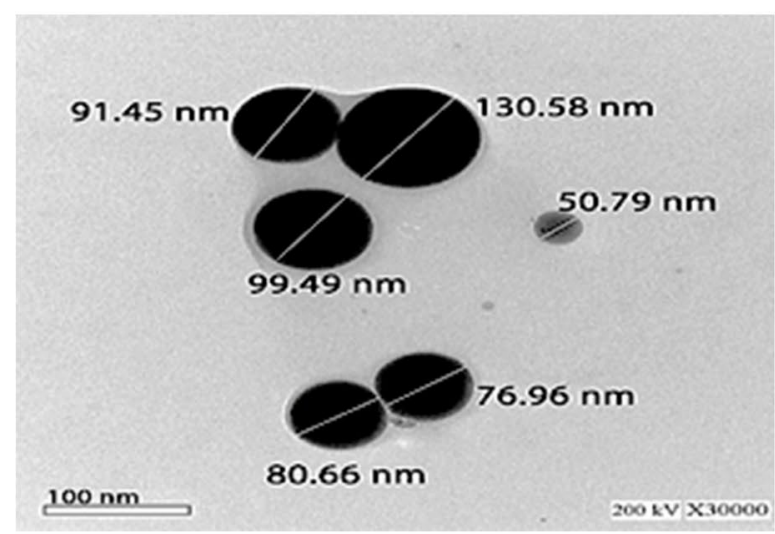

A

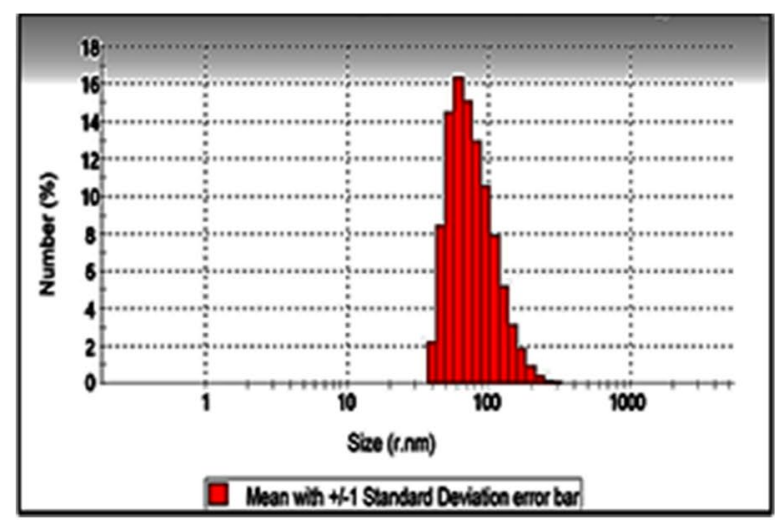

C

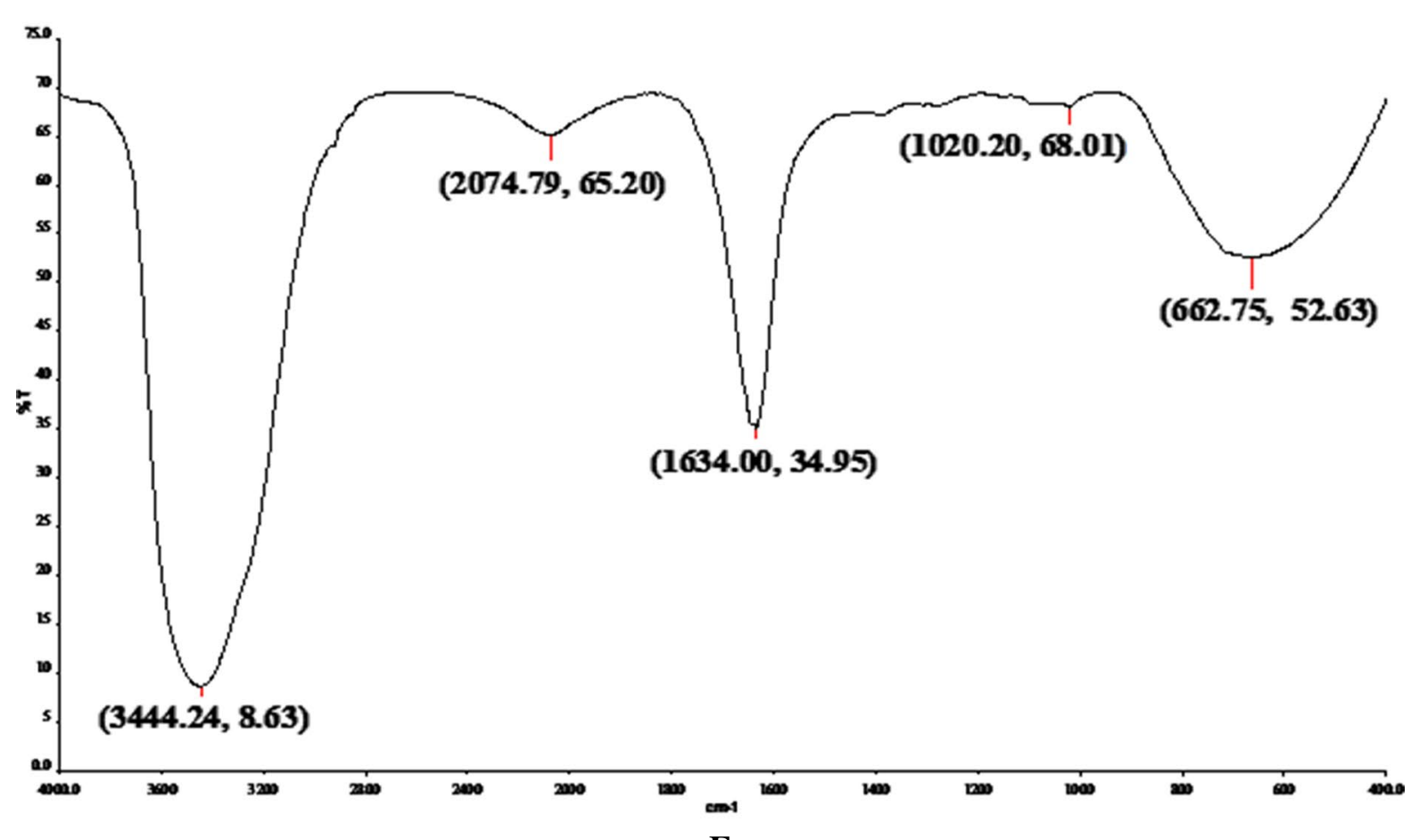

$\mathbf{E}$

Fig. 2 TEM image with scale bar $=100 \mathrm{~nm}, \mathrm{~b}$ absorption spectrum by scanning spectrophotometer, c histogram of DLS analysis for nanoparticles size distribution, $\mathrm{d}$ photo of CTS-SeNPs samples: A before nano-

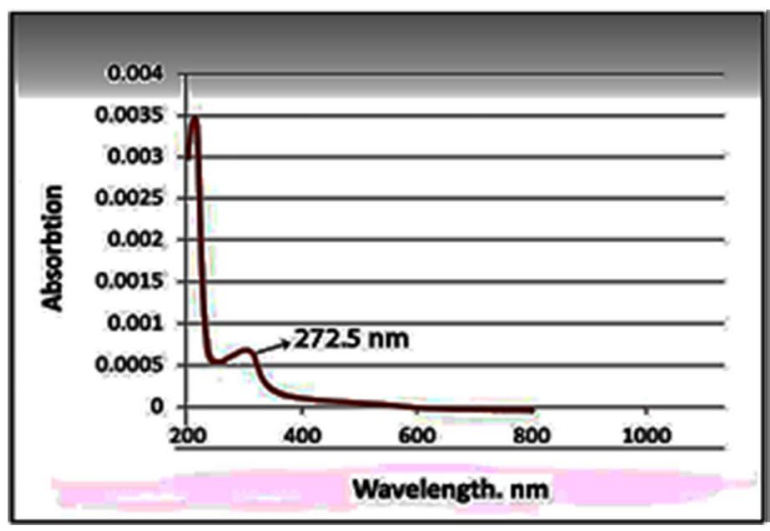

B

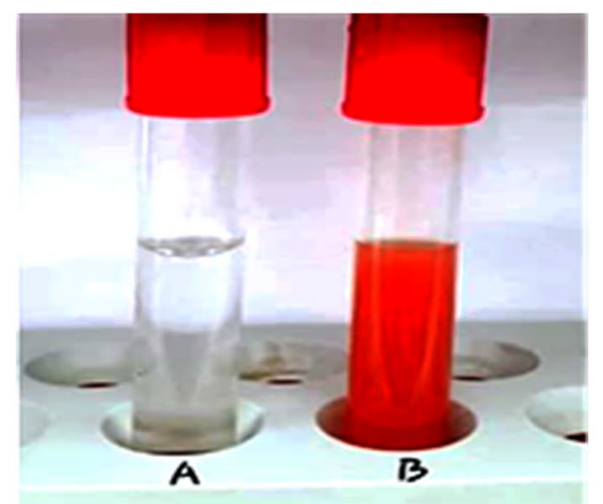

D 
Table 3 Effect of STZ, CTSSeNPs, or Glib on serum glucose, insulin, and IGF-1 levels

\begin{tabular}{lcll}
\hline & Glucose $(\mathbf{m g} / \mathbf{d l})$ & Insulin $(\mathbf{n g} / \mathbf{m L})$ & IGF-1 $($ Pg/mg protein) \\
\hline Control & $87.2 \pm 2.7^{\mathrm{a}}$ & $2.1 \pm 0.08^{\mathrm{a}}$ & $33.3 \pm 2.2^{\mathrm{a}}$ \\
CTS-SeNPs & $86.3 \pm 5.2^{\mathrm{a}}$ & $2.2 \pm 0.17^{\mathrm{a}}$ & $30.5 \pm 4.9^{\mathrm{a}}$ \\
Glib & $70.0 \pm 4.2^{\mathrm{a}}$ & $2.2 \pm 0.12^{\mathrm{a}}$ & $31.2 \pm 2.3^{\mathrm{a}}$ \\
STZ & $599.0 \pm 38^{\mathrm{b}}$ & $1.4 \pm 0.19^{\mathrm{b}}$ & $11.5 \pm 3.5^{\mathrm{b}}$ \\
STZ+CTS-SeNPs & $87.0 \pm 7.4^{\mathrm{a}}$ & $1.8 \pm 0.23^{\mathrm{c}}$ & $24.5 \pm 11.0^{\mathrm{c}}$ \\
STZ+Glib & $167.8 \pm 30.4^{\mathrm{c}}$ & $1.9 \pm 0.11^{\mathrm{d}}$ & $29.8 \pm 4.2^{\mathrm{d}}$ \\
\hline
\end{tabular}

Fig. 3 Effect of STZ, CTSSeNPs, or Glib treatment on serum A: $\alpha$-glucosidase, B: $\alpha$-amylase activities in different groups. Values are expressed as mean \pm SD in each group $(n=8)$. Different symbols are significant at $p \leq 0.05$ (Duncan's test)

Fig. 4 Effect of STZ, CTSSeNPs, or Glib treatment on body weight in different animal groups. Values are expressed as mean $\pm \mathrm{SD}$
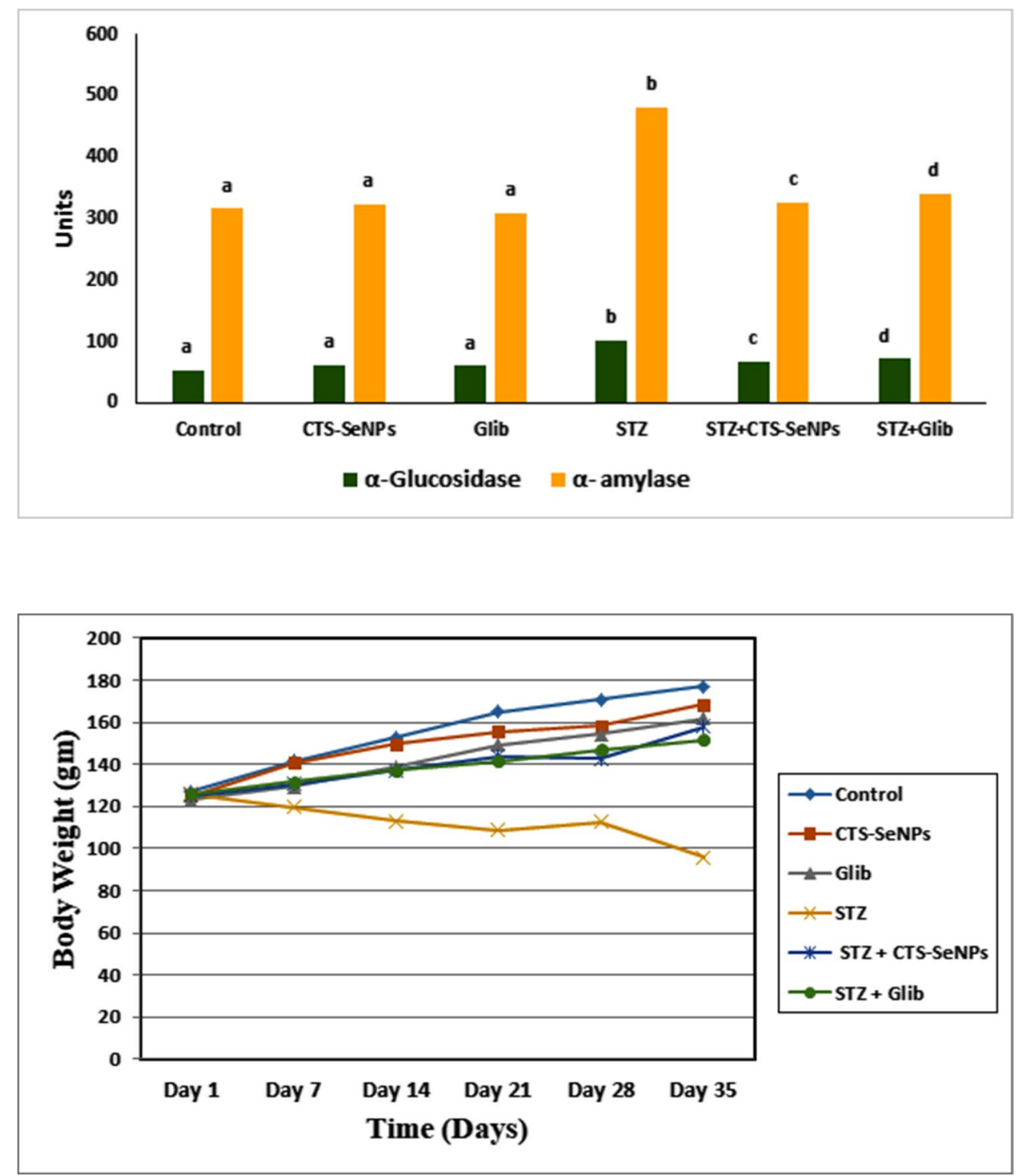

\section{Effects of CTS-SeNPs on Body Weight in CTS-SeNPs-Fed Rats}

Results presented in Fig. 4 of BW showed insignificant changes $(p>0.05)$ in BW levels of CTS-SeNPs and Glib groups compared to control group. Treating male rates with STZ showed significant decrease in BW level compared to control group. On the other hand, treating diabetic rats with CTS-SeNPs or Glib showed significant increase $(p \leq 0.05)$ in BW in STZ+CTSSeNPs and STZ+ Glib groups compared to STZ group. 
Fig. 5 Changes in serum CAT, GSH, TAC, and MDA levels among different groups after treatment with STZ, CTS-

SeNPS, or Glib. Values are expressed as mean \pm SD in each group $(n=8)$. Different symbols are significant at $p \leq 0.05$ (Duncan's test)

Fig. 6 STZ, CTS-SeNPs, or Glib post treatment changes in serum TNF- $\alpha$, IL- 6 , and IL-1 $\beta$ levels among different groups. Values are expressed as mean $\pm \mathrm{SD}$ in each group $(n=8)$. Different symbols are significant at $p \leq 0.05$ (Duncan's test)

Fig. 7 Effect of STZ, CTSSeNPs, or Glib on serum ALT, AST, ALP, GGT, total bilirubin, albumin, and CK-MB. Values are expressed as mean \pm SD in each group $(n=8)$. Different symbols are significant at $p \leq 0.05$ (Duncan's test)
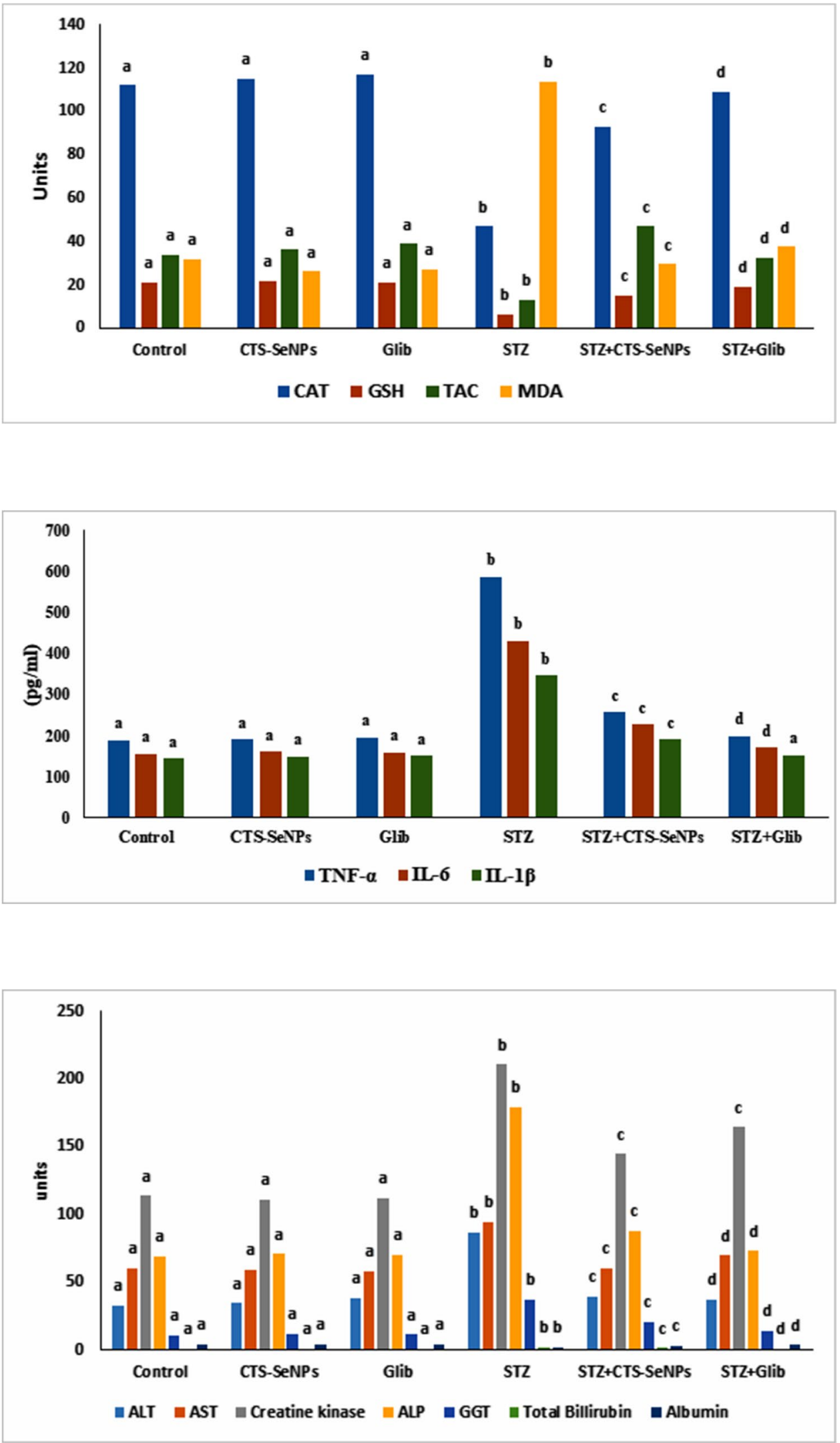
Table 4 Effect of STZ, CTSSeNPs, or Glib on serum lipid profile

\begin{tabular}{lcccc}
\hline & $\begin{array}{c}\text { Total choles- } \\
\text { terol }(\mathbf{m g} / \mathbf{d l})\end{array}$ & Triacylglycerol mg/dl) & HDL-C (mg/dl) & LDL-C (mg/dl) \\
\hline Control & $104.5 \pm 3.6^{\mathrm{b}}$ & $67.5 \pm 2.7^{\mathrm{b}}$ & $38.7 \pm 1.2^{\mathrm{b}}$ & $59.0 \pm 2.4^{\mathrm{b}}$ \\
CTS-SeNPs & $102.3 \pm 4.6^{\mathrm{b}}$ & $67.8 \pm 4.5^{\mathrm{b}}$ & $39.0 \pm 1.3^{\mathrm{b}}$ & $55.3 \pm 3.8^{\mathrm{b}}$ \\
Glib & $88.5 \pm 39^{\mathrm{b}}$ & $67.5 \pm 5.4^{\mathrm{b}}$ & $38.1 \pm 1.5^{\mathrm{b}}$ & $49.2 \pm 3.1^{\mathrm{a}, \mathrm{b}}$ \\
STZ & $206.5 \pm 11.1^{\mathrm{a}}$ & $179.0 \pm 5.3^{\mathrm{a}}$ & $18.2 \pm 0.98^{\mathrm{a}}$ & $157.7 \pm 9.2^{\mathrm{a}}$ \\
STZ+CTS-SeNPs & $102.7 \pm 4.2^{\mathrm{b}}$ & $66.3 \pm 3.0^{\mathrm{b}}$ & $37.8 \pm 1.9^{\mathrm{b}}$ & $56.0 \pm 4.2^{\mathrm{b}}$ \\
STZ+Glib & $104.7 \pm 7.5^{\mathrm{b}}$ & $63.8 \pm 3.2^{\mathrm{b}}$ & $38.3 \pm 1.5^{\mathrm{b}}$ & $55.2 \pm 5.6^{\mathrm{b}}$ \\
\hline
\end{tabular}

Values are expressed as mean $\pm \mathrm{SD}$ in each group $(n=8)$. Different symbols are significant at $p \leq 0.05$ (Duncan's test).

\section{Effect of STZ, CTS-SeNPs, or Glib on Serum Antioxidant and Oxidative Stress Markers}

Treating normal rats with STZ induced an oxidative stress as revealed from the massive reduction in the levels of serum GSH, TAC, and CAT activity with the significant augmentation in MDA level, compared to their normal counterparts. On the opposite side, administration of CTS-SeNPs or Glib to diabetic rats ameliorated the above parameters, compared to STZ group (Fig. 5).

\section{Effect of STZ, CTS-SeNPs, or Glib on Proinflammatory Markers}

The levels of serum proinflammatory parameters (TNF- $\alpha$, IL-6, and IL-1 $\beta$ ) in control and treated animals are illustrated in Fig. 6. Treating normal animals with STZ produced a marked elevation in serum levels of the studied proinflammatory parameters, versus normal control. Administrating CTSSeNPs or Glib to diabetic rats significantly reduced serum levels of the proinflammatory parameters.

\section{Effect of STZ, CTS-SeNPs, or Glib on Serum Liver and Cardiac Enzymes}

Intraperitoneal injection of normal animals with STZ significantly elevated serum hepatic and cardiac enzymes (ALT, AST, ALP, GGT, total bilirubin, albumin, and CK-MB), compared to normal group. Administrating CTS-SeNPs or Glib to diabetic rats ameliorated the above enzymes (Fig. 7).

\section{Effect of STZ, CTS-SeNPs, or Glib on Serum Lipid Profile}

Table 4 revealed that administration of STZ to normal rats induced a marked elevation in the levels of serum total cholesterol, TG, and LDL-C with a significant reduction in the level of HDL-C, as compared with normal group.
Treating diabetic animals with CTS-SeNPs or Glib ameliorated the aforementioned parameters.

\section{Quantitative Real-Time PCR Analysis of TC7L2, CAPN10, and PPAR- $\gamma$}

The expression levels of TC7L2 and CAPN10 genes in the pancreatic cells of STZ treated rats were significantly increased $(p \leq 0.05)$, compared to control group. On the other hand, STZ-treated animals exhibited a marked downregulation in PPAR- $\gamma$ gene, compared to their normal counterparts. Treating diabetic rats with either CTS-SeNPs or Glib led to downregulation of both TC7L2 and CAPN10 genes with an upregulation of PPAR- $\gamma$ gene compared to STZ-treated rats (Fig. 8a and b).

\section{Histopathological Findings}

Histopathological investigation of pancreatic tissue under the light microscope of (A) control animals, (B) CTS-SeNPs, and (C) Glib groups revealed normal texture pattern with contact islets of Langerhans and normal thickness septa, respectively. In STZ group (Fig. 9D), septa was wider than the remaining groups, the islets of Langerhans showed signs of atrophy and shrinking. Infiltrated lymphocytes were seen which indicates inflammation of these cells. Diabetic animal groups treated with CTS-SeNPs or Glib revealed restoration of normal shape and size of pancreatic cells (Fig. 9E and F), respectively. The score for the histopathological investigation of different parts of pancreatic tissue is illustrated in Table 5 .

\section{Discussion}

Diabetes mellitus is considered a major global health issue that has reached alarming levels. It is a cluster of several chronic lifelong metabolic endocrine disorders with 
Fig. 8 Changes in pancreatic TC7L2, PPAR- $\gamma$, and CAPN10 gene expression levels among different groups. Values are expressed as mean \pm SD in each group $(n=8)$. Different symbols are significant at $p \leq 0.05$

(Duncan's test). b Heatmap diagrams for changes in pancreatic TC7L2, PPAR- $\gamma$, and CAPN10 gene expression levels among different groups. The red color indicates the higher fold change gene expression, and the green color refers to the lower ones

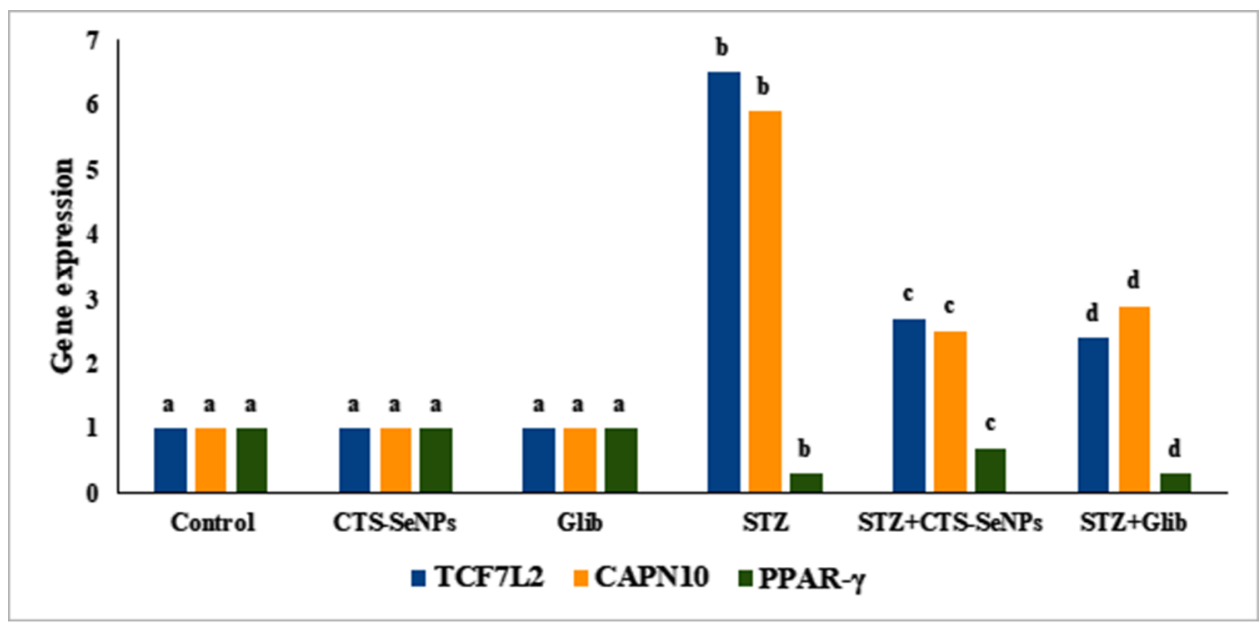

(a)

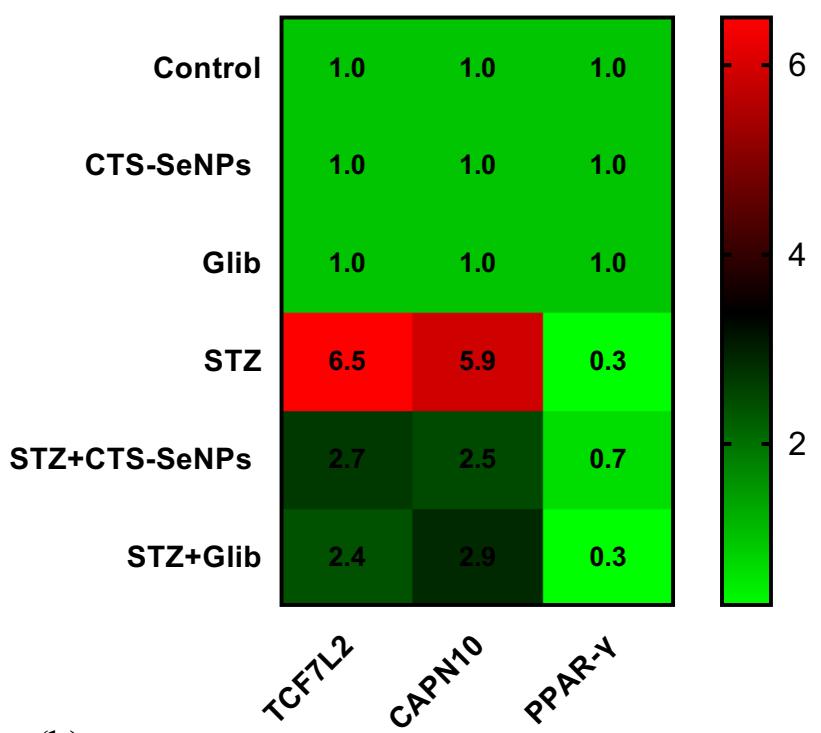

(b)

long-term damage, dysfunction, and failure of various organs, especially the eyes, kidneys, nerves, heart, and blood vessels $[24,25]$. Epidemiological studies reveal that the incidence of diabetes is on the rise around the world, with an estimation of approximately 387 million people. This figure is predicted to rise to 590 million by 2035 [26].

Our results demonstrated a significant decrease in serum IGF-1 levels in STZ treated animals compared to the control group. Rajpathak et al., Chu et al., and Zhang et al. [39-41] recorded the association of the reduction in IGF-1 level with the decrease in insulin concentration in diabetes mellitus.

According to Ramesh [27], the main causes of the pathogenesis of diabetes are elevated oxidative stress and mitochondrial dysfunction. Diabetes mellitus is characterized by hyperglycemia associated with increased formation of ROS, reactive nitrogen species, advanced glycation end products, elevated lipolysis, ketogenesis, and diminished levels of antioxidants. Baynes [28] proved that uncontrolled ROS production frequently causes damage to cellular macromolecules (DNA, lipids, and proteins), contributing to the progression of diabetic complications and different organ damage. The generation of ROS due to hyperglycemia stimulates apoptosis, further leading to diabetic microvascular complications. So, it is necessary to investigate new clinical therapies against oxidative stress as additional standard treatments for diabetic patients [29].

In the present work, the potential antidiabetic and antioxidant effects of SeNPs capped with chitosan (CTS-SeNPs) as natural products were investigated in an STZ-induced diabetic model. Glibenclamide (Glib) was used as a reference pharmaceutical product in the treatment of diabetes. Chitosan is an attractive agent for drug development given its function in the gastrointestinal tract and its intrinsic safety when taken orally, as it improves solubility, escalates cellular 
Fig. 9 Histopathological photographs of pancreatic tissue: (A) normal control, (B) CTS-SeNPs, (C) Glib, (D) STZ, (E) STZ+CTS-SeNPs, and (F) STZ+ Glib. Arrows representing average-sized palestaining islets of Langerhans (black arrows), exocrine areas (blue arrows), average ducts (red arrow), and interstitial blood vessels (yellow arrow) $(\mathrm{H} \& \mathrm{E} \times 200)$

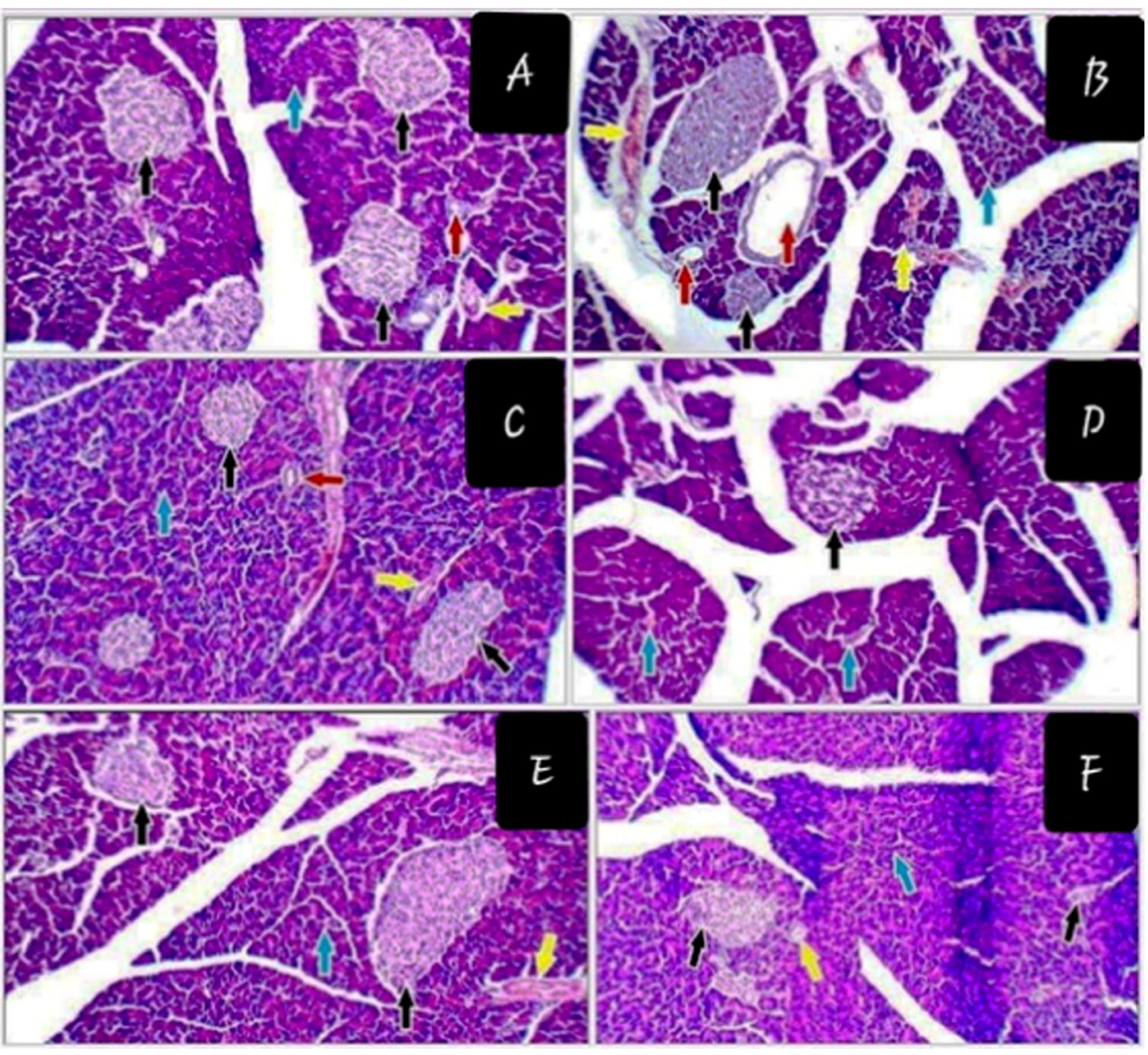

\begin{tabular}{lllllllll}
\hline Groups & \multicolumn{2}{l}{ Pancreatic islets } & & $\begin{array}{l}\text { Exocrine } \\
\text { area }\end{array}$ & Ducts & BV \\
\cline { 2 - 7 } & Islet size & Cellularity & Beta cells & Edema & Capillaries & & & \\
\hline A & 0 & 0 & 0 & 0 & 0 & 0 & 0 & 0 \\
B & 0 & 0 & 0 & 0 & ++ & 0 & + & ++ \\
C & 0 & 0 & 0 & 0 & 0 & 0 & 0 & 0 \\
D & + & + & + & + & + & 0 & 0 & + \\
E & 0 & 0 & 0 & 0 & 0 & 0 & 0 & 0 \\
F & 0 & + & 0 & 0 & 0 & 0 & 0 & 0 \\
\hline
\end{tabular}

Table 5 Histopathological results of pancreatic tissue group (-OH), amid I of proteins, and carbon with $-\mathrm{H}$ or $-\mathrm{N}$. These findings coincide with $\mathrm{Wu}$ et al [35] who reported that FTIR analysis of SeNPs produced using CTS represented peaks observed at 3449,1648 , and $1030 \mathrm{~cm}-1$ regarded as $\mathrm{O}-\mathrm{H}$ or $\mathrm{N}-\mathrm{H}$ stretch.

In the present research, STZ $(50 \mathrm{mg} / \mathrm{kg}$. b.wt) was intraperitoneally administered to normal rats to induce diabetes mellitus. This was revealed by the elevation of serum glucose levels and the reduction in serum insulin levels. Robertson [36] reported that diabetes mellitus comprises a group of chronic diseases characterized by hyperglycemia or diminished insulin secretion or both. The decrease in serum insulin levels in animal models after STZ induction is used as a sign of the inducement of diabetes [37]. Streptozotocin 
action in $\beta$-cells is accompanied by abnormalities in $\beta$-cell function. STZ inhibits glucose oxidation and reduces insulin synthesis [38]. Pancreatic $\beta$-cell toxicity and diabetic conditions resulting from STZ induction are related to the glucose moiety in its chemical structure, which enables STZ to enter the $\beta$-cells via the low affinity GLUT- 2 transporter in the plasma membrane [39], because the $\beta$-cells of the pancreas are more active than other cells in taking up glucose and so are more sensitive than other cells to STZ challenge.

IGF-1 is a peptide hormone that shares amino acid sequence homology with insulin. It has an insulin-like activity [40]. In addition, IGF-I may have beneficial effects on systemic inflammation, a diabetic risk factor, and on the mass and function of pancreatic $\beta$-cells. Its administration to diabetes patients improved their insulin sensitivity [41]. Our results demonstrated a significant decrease in serum IGF-1 levels in STZ-treated animals compared to the control group. Rajpathak et al., Chu et al., and Zhang et al. [41-43] recorded the association of the reduction in IGF-1 level with the decrease in insulin concentration in diabetes mellitus.

In the current work, STZ-induced diabetic rats were treated with the CTS-SeNPs, causing a marked decrease in glucose levels with an increase in insulin and IGF-1 levels. Selenium is an insulin mimetic, which explains its ability to reduce the levels of glucose [44]. Our findings are comparable to those of Vural et al. [45], who observed a reduction in the serum glucose levels of diabetic rats after treatment with sodium selenite. It has been reported that selenate enhanced the transportation and uptake of glucose in adipocytes of rats by translocating glucose transporters, such as GLUT-1 and GLUT-2, to the surface of many membranes [46]. Furthermore, the glucose lowering effect of Se might be supported by other mechanisms, such as an acceleration of kidney glucose excretion in rats or stimulation of adipogenesis in adipocytes via stimulating serine/threonine kinases, including the p70 S6 kinase [47]. Also, Guo et al. [48] reported that chitosan improves blood glucose levels and exerts its antidiabetic effect by upregulating the expression of glucose transporters.

The proposed mechanism of Se enhancing insulin action includes activation of insulin receptor sites, serving as cofactors or components for enzyme systems involved in glucose metabolism [49]. Also, Bai et al. [50] reported that selenium's antidiabetic action results from its behavior as an antioxidant nutrient, since insulin signaling and secretion are associated with the cellular redox state [51]. Similarly, Campbell et al. [52] found that selenium participates in insulin's action on $\beta$-pancreatic cells through its ability to regulate the gene expression of insulin promoter factor 1 and to increase the mRNA expression of insulin in the mouse $\beta$-cell of Min6 cells.

The increase of IGF-1 in the diabetic group treated with SNPs may be connected to the earlier reported decrease in both inflammatory activity and oxidative stress, which was caused by supplemental selenium [53].

In our results, Glib administration in diabetic rats showed a significant decrease in glucose and an increase in insulin and IGF-1 levels. The mode of action of Glib in hyperglycemic conditions is to lower blood glucose via stimulating insulin production from the existing $\beta$-cells of the pancreas by inhibiting ATP-sensitive potassium channels in pancreatic $\beta$-cells. Glibenclamide This inhibition causes the cell membrane to increase insulin secretion due to the closure of potassium-ATP channels, opening voltage-dependent calcium channel. It also improves glucose utilization and, as a result, insulin release [54].

$\alpha$-Amylase and $\alpha$-Glucosidase are carbohydrate-metabolizing enzymes involved in the breakdown of long chain carbohydrates, starch, and disaccharides to glucose, respectively [55]. Our findings represented elevated $\alpha$-glucosidase and $\alpha$-amylase activities in STZ-treated rats. On the other hand, administration of CTS-SeNPs or Glib to diabetic rats significantly reduced $\alpha$-amylase and $\alpha$-glucosidase activities. Inhibition of $\alpha$-amylase and $\alpha$-glucosidase therefore slows the release of absorbable monosaccharides from dietary complex carbohydrates, postpones the absorption of glucose into the blood, and thus avoids any sudden increase in the amount of blood glucose post meals [56]. Chitosan-SeNPs have been shown to lower serum glucose concentrations by inhibiting the activity of $\alpha$-amylase and $\alpha$-glucosidase [57]. Furthermore, Guo et al. [48] reported that chitosan exerts its antidiabetic effect by inhibiting the expression of intestinal $\alpha$-amylase and $\alpha$-glucosidase. Moreover, McCue et al. [58] indicated that delaying carbohydrate absorption with Glib offers a prospective therapeutic approach for management of $\alpha$-amylase and $\alpha$-glucosidase activities in DM and may be beneficial for borderline diabetic patients.

Our results showed a significant decrease in the body weight of diabetic rats. This could be attributed to the increased catabolic reactions due to the inability to utilize carbohydrates as an energy source, leading to muscle waste [59]. Treating diabetic rats with CTS-SeNPs or Glib restores body weight through the experimental period. This could be due to a post-treatment increase in insulin levels that improved glycemic control, thereby preventing weight loss [60]. Kumar et al. [61] observed that SeNPs had a great effect on restoring body weight. Furthermore, SeNPs had dramatically higher effects on increasing the body weight of diabetic rat. Using chitosan may also improve SeNPs' effects. Also, Obafemi et al. [62] confirmed that treatment with Glib improves body weight significantly and prevents muscle wasting due to hyperglycemic conditions.

Hyperglycemia causes oxidative stress due to increased mitochondrial production of the superoxide anion, nonenzymatic glycation of protein, and glucose autoxidation. Oxidative stress occurs as a result of either overproduction 
of ROS or insufficiency of antioxidant defense systems, thus disrupting redox signaling, and is, therefore, implicated in the pathogenesis of major human diseases [63].

The STZ injection induced a state of oxidative stress manifested by elevation of lipid peroxidation and depletion of the enzymatic and non-enzymatic antioxidants in the diabetic rats versus the normal group. In comparison, administration of CTS-SeNPs or Glib in diabetics enhanced the levels of GSH, TAC, and CAT activity. It also ameliorated the levels of MDA, compared to diabetic animals. SeNPs have antioxidant properties along with stimulating antioxidant enzymes that induced scavenging various peroxides. That protects membrane lipids and cellular macromolecules from oxidative injury, decreases MDA concentration, and increases TAC [47]. In addition, CTS plays a role in the induction of free radical scavenging and anti-oxidative enzyme production to suppress oxidative stress by inducing anti-oxidative enzymes and acting as ROS scavengers [64].

A study conducted by Obi et al. [65] clarified that glib has some protective role against oxidative damage in hyperglycemic conditions. An earlier study also agrees with our results, showing that the STZ diabetic rats treated with glib showed a significant reduction in MDA [66].

The liver plays a very important role in the maintenance of glucose levels in the body. It regulates the metabolism of glucose by using glucose molecules as an energy source. Diabetes mellitus may lead to liver-associated diseases such as non-alcoholic fatty liver disease (NAFLD) [67, 68]. ALT, AST, ALP, GGT, total bilirubin, and albumin are considered markers of liver toxicity. According to our observations, STZ-treated animals showed an increase in serum levels of ALT, AST, ALP, GGT, total bilirubin, and albumin. Our results are in agreement with the findings of Ghimire et al. [69], who showed that ALT, AST, ALP, GGT, total bilirubin, and albumin levels were significantly increased in the liver of STZ-treated animals with insulin deficiency, and these changes can be associated with the increase in gluconeogenesis and ketogenesis during diabetes. Treating diabetic rats with either CTS-SeNPs or Glib restored the activities of ALT, AST, ALP, GGT, total bilirubin, and albumin markers to normal values. Al-Quraishy et al. [47] suggested that SeNPs ameliorated STZ dysfunction through radical scavenging activity, besides its integrity and functions of liver tissues resulting from the role of SeNPs in treating liver dysfunction. Moreover, the hepatoprotective effects of chitosan against hepatotoxicity may also have contributed to its antiinflammatory effect, as shown by reduction of liver enzyme levels [70]. The effects of Glib against diabetes-associated liver injury were confirmed by the decrease in the serum activities of AST and ALT. This effect was concomitant with the improved glucose level [71].

Cardiovascular complications caused by uncontrolled hyperglycemia are widely regarded as one of the leading causes of morbidity and mortality in diabetic patients [72]. Oxidative stress and inflammation have been implicated in playing a central role in the progression of dilated cardiomyopathy (DCM) [73]. Actually, CK-MB is used as a marker of myocardial injury [74]. The current study presented an increase in the circulating values of CK-MB in diabetic rats. These findings were supported by [75]. Treating diabetic rats with CTS-SeNPs significantly lowered CKMB serum levels. Selenium suppresses cardiomyocyte apoptosis through inhibiting the p38MAPK/CBP pathway [76]. Furthermore, selenium restores depressed $\beta$-adrenergic responses of the heart in diabetic rats [77]. Besides its antioxidant, hypolipidemic effects [45], and anti-inflammatory activity, it has a beneficial effect on the regulation of the leukotriene pathway in diabetic cardiac hypertrophy hearts [78]. Also, Sutthasupha and Lungkaphin [64] reported the ameliorative effect of chitosan on diabetic cardiomyopathy.

In the setting of diabetes, some sulfonylureas like Glib have been found to inhibit the activity of the ATP-sensitive potassium channels (KATP), resulting in ischemic preconditioning inhibition [79]. In our study, results showed a significant decrease in CK-MB activities in diabetic rats treated with Glib. Glib has more affinity for cardiac monocytes [80]. This provides an explanation for the negative cardiovascular outcomes seen with Glib [79].

Abnormalities in lipid profiles are one of the most common complications in diabetes mellitus, found in $40 \%$ of diabetic cases [81]. Our results showed a marked increase in cholesterol, triacylglycerol, and LDL-c with a significant decrease in HDL-c in diabetic rats. Abnormally high concentrations of plasma lipids in diabetes are mainly due to an increase in the mobilization of free fatty acids from the peripheral depots in the absence or deficiency of insulin. Hence, during diabetes, hepatic lipogenesis is decreased, and lipolysis is increased [82]. Insulin deficiency or resistance may be responsible for dyslipidemia, because insulin has an inhibitory action on 3-hydroxy-3-methylglutaryl coenzyme A (HMG-COA) reductase, a key enzyme which is responsible for the metabolism of LDL-c particles rich in cholesterol [83]. Moreover, altered HDL composition in patients with diabetes results in a diminished ability to promote reverse cholesterol transport. Impeded cholesterol efflux from adipose and hepatic cells is mainly related to increased triacylglycerol and decreased cholesterol content of HDL [84]. Jiang et al. [85] demonstrated that the oral treatment of SeNPs results in a remarkable decrease in serum levels of cholesterol, triacylglycerol, and HDL-c which is linked with a significant decrease in LDL-c levels compared to the untreated diabetic rats. The increased HDL-c levels could raise the efflux of cholesterol and triacylglycerol from liver tissue for catabolism. This would result in a reduction in cholesterol triacylglycerol in the blood. These findings are in agreement with our observations. 
One of the genes identified in relation to diabetes risk is the transcription factor 7-like 2 gene (TCF7L2). It is the major transcription factor and one of the components of the canonical WNT signaling pathway and is mainly expressed in human pancreatic beta cells and adipose tissue [86]. TCF7L2 has an important role in glucose homeostasis, the generation of insulin resistance, and lipid metabolism [87]. High expression of this gene results in impaired glucosestimulated insulin secretion [88]. Low insulin secretion and the risk of DM are associated with TCF7L2 because it is a suppressor of GLP-1 in the intestines [89]. Moreover, TCF7L2 functions as a co-activator of $\mathrm{p} 65$ to potentiate inflammatory cytokine production in macrophages to aggravate induced chronic inflammation and insulin resistance in mice. Our results indicated that STZ treatment induced an upregulation of the aforementioned gene with the elevation of the inflammatory markers (TNF- $\alpha$, IL- $1 \beta$, and IL- 6 ), confirming the incidence of DM and inflammation.

Treating of diabetic rats with CTS-SeNPs or Glib resulted in the downregulation of TCF7L2 gene expression with a reduction in the levels of inflammatory markers, compared to the diabetic group. This coincides with that reported by [90-92].

Calpain-10 (CAPN10) is a $\mathrm{Ca}^{2+}$-dependent cysteine protease that regulates glucose homeostasis in pancreatic islet cells, liver, skeletal muscle, and adipocytes [93]. It has an essential function in proinsulin processing and insulin production and activity [94]. This study showed that CAPN10 gene expression was upregulated in STZ-treated rats. Oxidative stress increases intracellular free $\mathrm{Ca}^{2+}$ levels and activates $\mathrm{Ca}^{2+}$-dependent enzymes which mediate apoptosis [95-97]. In our study, treatment with CTS-SeNPs or Glib resulted in a downregulation of CAPN10 gene expression compared to the diabetic group. SeNPs were found in intronic regions, where they altered gene expression of CAPN10 alternative splicing mechanisms [98].

Peroxisome proliferator-activated receptors- $\gamma(\operatorname{PPAR} \gamma)$ are glycolysis proteins that maintain glucose homeostasis in the liver and pancreas by activating glucokinase and glucose transporter 2 (GLUT2). This gene is associated with postprandial hypertriglyceridemia and plays a major role in the development of diabetes mellitus [99].

In the present investigation, STZ administration resulted in a significant downregulation in (PPAR- $\gamma$ ) gene expression compared with normal nondiabetic animals. CTSSeNPs or Glib treatment, on the other hand, significantly increased PPAR- $\gamma$ mRNA expression. Studies have documented that activation of PPAR regulates various genes involved in cell growth and differentiation, inflammatory pathways, insulin sensitivity, angiogenesis, lipid, and glucose metabolism [100]. Peroxisome proliferator-activated receptors- $\gamma$ have also been shown to inhibit the release of proinflammatory cytokines from macrophages, such as
TNF- $\alpha$ and ILs, resulting in pain relief [101]. In contrast, PPAR- $\gamma$ inhibition activates nuclear factor-kB, resulting in the release of various proinflammatory cytokines (TNF- $\alpha$ and IL-1 $\beta$ ), which further activates the pain pathway.

Thus, activation of the PPAR-gene produces an antiinflammatory effect [101]. The activation of PPAR- $\gamma$ by CTS-SeNPs treatment is the central mechanism behind the amelioration of diabetic complications and various disease states. Similarly, chitosan exerts its antidiabetic effect by improving the expression of PPAR $\gamma$ [48]. Another study suggested that chitosan prevents hyperglycemia by inhibiting intestinal glucose digestion and helps in transporting and enhancing glucose uptake, at least in part, by upregulating PPAR $\gamma$ expression of adiponectin in adipocytes [48].

Our observations revealed significant upregulation of PPAR $\gamma$ gene expression in diabetic groups treated with Glib. These results indicated strong correlations between PPAR $\gamma$ and the antidiabetic action of sulfonylureas such as Glib. Also, some studies have reported the relative potency of sulfonylureas for binding to PPAR $\gamma$ and activation of PPAR $\gamma$ in vitro, which is well associated with their antidiabetic potency in vivo [102].

The histopathological analysis in the present work goes along with the biochemical and molecular studies. STZ treatment induced toxicity, and damaging signs appeared in the atrophy of the island of Langerhans cells, small-sized pale-staining hypocellular, apoptotic $\beta$-cells, predominating alpha cells, and congested blood capillaries. Pisarev et al. [103] concluded that the STZ can cause cellular necrosis and selective destruction of $\beta$-cells via its direct alkylating action. On the other hand, CTS-SeNPs-treated diabetic rats showed normal histological structure of the island of Langerhans cells, with average-sized pale-staining islets of Langerhans composed of predominating $\beta$-cells. Wang et al. [104] reported that SeNPs limited the dysfunction of $\beta$-cells by inhibiting apoptosis and oxidative stress. Notably, chitosan has been shown to promote the proliferation of $\beta$-cells and the recovery of damaged $\beta$-cell functions, which can produce insulin and thus increase insulin sensitivity [48]. Our results demonstrated that Glib-treated diabetic animals showed regression in cell atrophy caused by STZ with predominating $\beta$-cell cytoplasm and newly pancreatic $\beta$-cells are present.

\section{Conclusion}

The current investigation demonstrated the therapeutic effect of CTS-SeNPs against experimentally induced diabetes mellitus in adult male rats. This effect is afforded by the antioxidant, hypoglycemic, and hypolipidemic properties of CTS-SeNPs, as a result of using selenium and chitosan. 
Along with improving vital organ function (pancreas, liver, and heart).

\begin{abstract}
Author Contribution All authors contributed to the study conception and design. Material preparation, data collection, and analysis were performed by Omayma A. R. Abozaid, Sawsan M. El-Sonbaty, Neama M. A. Hamam, Moustafa A. Farrag, and Ahmad S. Kodous. The first draft of the manuscript was written by Ahmad S. Kodous, and all authors commented on previous versions of the manuscript. All authors read and approved the final manuscript.
\end{abstract}

Funding Open access funding provided by The Science, Technology \& Innovation Funding Authority (STDF) in cooperation with The Egyptian Knowledge Bank (EKB).

Data Availability All the data are available in the current study.

\section{Declarations}

Ethics Approval The experimental protocol was carried out according to the Guide for the Care and Use of Laboratory Animals (NIH No. 85-23, 1985)

Statement of Human and Animal Rights All the ethical protocols for animal treatment were followed by the National Institutes of Health guide for the care and use of laboratory animals and supervised by the animal facilities, National Centre for Radiation Research and Technology, Atomic Energy Authority.

Competing Interests The authors declare no competing interests.

Open Access This article is licensed under a Creative Commons Attribution 4.0 International License, which permits use, sharing, adaptation, distribution and reproduction in any medium or format, as long as you give appropriate credit to the original author(s) and the source, provide a link to the Creative Commons licence, and indicate if changes were made. The images or other third party material in this article are included in the article's Creative Commons licence, unless indicated otherwise in a credit line to the material. If material is not included in the article's Creative Commons licence and your intended use is not permitted by statutory regulation or exceeds the permitted use, you will need to obtain permission directly from the copyright holder. To view a copy of this licence, visit http://creativecommons.org/licenses/by/4.0/.

\section{References}

1. Williams R, Karuranga S, Malanda B, Saeedi P, Basit A, Besançon S, Bommer C, Esteghamati A, Ogurtsova K, Zhang P, Colagiuri S (2020) Global and regional estimates and projections of diabetes-related health expenditure results from the International Diabetes Federation Diabetes Atlas th edition. Diabetes Res Clin Pract 162:108072

2. Xiong J, Hu H, Guo R, Wang H, Jiang H (2021) Mesenchymal Stem Cell Exosomes as a new strategy for the treatment of diabetes complications. Front. Endocrinol (Lausanne) 12:463

3. Cho NH, Shaw JE, Karuranga S, Huang Y, da Rocha Fernandes JD, Ohlrogge AW, Malanda B (2018) IDF Diabetes Atlas: global estimates of diabetes prevalence for 2017 and projections for 2045. Diabetes Res Clin Pract 138:271-281. https://doi.org/10. 1016/j.diabres.2018.02.023
4. Khan MAB, Hashim MJ, King JK, Govender RD, Mustafa H, Al Kaabi J (2020) Epidemiology of type 2 diabetes - global burden of disease and forecasted trends. J Epidemiol Glob Health 10:107-111. https://doi.org/10.2991/jegh.k.191028.001

5. Saeedi P, Petersohn I, Salpea P, Malanda B, Karuranga S, Unwin N, Colagiuri S, Guariguata L, Motala AA, Ogurtsova K, Shaw JE, Bright D, Williams R (2019) Global and regional diabetes prevalence estimates for 2019 and projections for 2030 and 2045: results from the International Diabetes Federation Diabetes Atlas, 9(th) edition. Diabetes Res Clin Pract 157:107843. https://doi.org/10.1016/j.diabres.2019.107843

6. Fukunaka A, Fujitani Y (2018) Role of zinc homeostasis in the pathogenesis of diabetes and obesity. Int J Mol Sci 19:476. https://doi.org/10.3390/ijms19020476

7. Wellen KE, Hotamisligil GS (2005) Inflammation, stress, and diabetes. J Clin Invest 115:1111-1119. https://doi.org/10.1172/ JCI25102

8. Mohammadi M, Gozashti MH, Aghadavood M, Mehdizadeh MR, Hayatbakhsh MM (2017) Clinical significance of serum IL-6 and TNF- $\alpha$ levels in patients with metabolic syndrome. Reports Biochem Mol Biol 6:74-79

9. U Galicia-Garcia, A Benito-Vicente, S Jebari, A Larrea-Sebal, H Siddiqi, KB Uribe, H Ostolaza, C Martín (2020) Pathophysiology of type 2 diabetes mellitus., Int. J. Mol. Sci. 21 https://doi. org/10.3390/ijms21176275

10. Rovenko BM, Perkhulyn NV, Lushchak OV, Storey JM, Storey KB, Lushchak VI (2014) Molybdate partly mimics insulinpromoted metabolic effects in Drosophila melanogaster. Comp Biochem Physiol Part C Toxicol Pharmacol 165:76-82. https:// doi.org/10.1016/j.cbpc.2014.06.002

11. Panchal SK, Wanyonyi S, Brown L (2017) Selenium, vanadium, and chromium as micronutrients to improve metabolic syndrome. Curr Hypertens Rep 19:10. https://doi.org/10.1007/ s11906-017-0701-x

12 Odawara M, Aoi S, Takeshima T, Iwasaki K (2021) Comparative effects of metformin and dipeptidyl peptidase- 4 inhibitors in japanese obese patients with type 2 diabetes: a claims database study., Diabetes Ther. Res. Treat. Educ. Diabetes Relat. Disord. 12:2165-2177. https://doi.org/10.1007/s13300-021-01101-2

13. van Gorp A-M, Rolfes L, Härmark L, van der Horst P, Hendriks J, Vorstenbosch S (2020) Insight in the safety profile of antidiabetic agents glucagon-like peptide- 1 agonists and dipeptidyl peptidase- 4 inhibitors in daily practice from the patient perspective. Pharmacoepidemiol Drug Saf 29:1588-1595. https://doi. org/10.1002/pds.5077

14 Rocha RF, Rodrigues T, Menegatti ACO, Bernardes GJL, Terenzi $\mathrm{H}$ (2020) The antidiabetic drug lobeglitazone has the potential to inhibit PTP1B activity. Bioorg Chem 100:103927. https://doi. org/10.1016/j.bioorg.2020.103927

15. Hien NQ, Tuan PD, Van Phu D, Quoc LA, Lan NTK, Duy NN, Hoa TT (2018) Gamma Co-60 ray irradiation synthesis of dextran stabilized selenium nanoparticles and their antioxidant activity. Mater Chem Phys 205:29-34. https://doi.org/10.1016/j.match emphys.2017.11.003

16. GA Birgani, A Ahangarpour, L Khorsandi, HF Moghaddam (2018) Anti-diabetic effect of betulinic acid on streptozotocin-nicotinamide induced diabetic male mouse model, Brazilian J. Pharm. Sci. 54 https://doi.org/10.1590/s2175-97902018000217171.

17. Zeng S, Ke Y, Liu Y, Shen Y, Zhang L, Li C, Liu A, Shen L, $\mathrm{Hu}$ X, Wu H, Wu W, Liu Y (2018) Synthesis and antidiabetic properties of chitosan-stabilized selenium nanoparticles. Colloids Surfaces B Biointerfaces 170:115-121. https://doi.org/10. 1016/j.colsurfb.2018.06.003

18. G. Kärber (1931) Beitrag zur kollektiven Behandlung pharmakologischer Reihenversuche, Naunyn. Schmiedebergs. Arch. Exp. Pathol. Pharmakol. 162 https://doi.org/10.1007/BF01863914 
19. Reeves PG (1997) Components of the AIN-93 diets as improvements in the AIN-76A diet. J Nutr. https://doi.org/10.1093/jn/ $127.5 .838 \mathrm{~s}$

20. Yang JK, Feng Y, Yuan MY, Yuan SY, Fu HJ, Wu BY, Sun GZ, Yang GR, Zhang XL, Wang L, Xu X, Xu XP, Chan JCN (2006) Plasma glucose levels and diabetes are independent predictors for mortality and morbidity in patients with SARS. Diabet Med 23:623-628. https://doi.org/10.1111/j.1464-5491.2006.01861.x

21. P. Trinder (1969) Determination of glucose in blood using glucose oxidase with an alternative oxygen acceptor, Ann Clin Biochem Int J Lab Med 6 https://doi.org/10.1177/000456326900600 108

22. AHB Wu, GN Bowers (1982) Evaluation and comparison of immunoinhibition and immunoprecipitation methods for differentiating $\mathrm{MB}$ from $\mathrm{BB}$ and macro forms of creatine kinase isoenzymes in patients and healthy individuals. Clin Chem 28 https://doi.org/10.1093/clinchem/28.10.2017

23. DR JD Banchroft, A Stevens, Turner, (1996) Theory and practice of histological techniques, 4th ed., Churchil Livingstone, New York, London, San Francisco, Tokyo, @ misc\%7Bbanchroft199 6theory, \%0A.

24 Nie Q, Hu J, Gao H, Fan L, Chen H, Nie S (2019) Polysaccharide from Plantago asiatica L. attenuates hyperglycemia, hyperlipidemia and affects colon microbiota in type 2 diabetic rats. Food Hydrocoll. 86:34-42. https://doi.org/10.1016/j.foodhyd.2017.12. 026

25. Nie X, Chen Z, Pang L, Wang L, Jiang H, Chen Y, Zhang Z, Fu C, Ren B, Zhang J (2020) Oral nano drug delivery systems for the treatment of type 2 diabetes mellitus: an available administration strategy for antidiabetic phytocompounds. Int J Nanomedicine 15:10215-10240. https://doi.org/10.2147/IJN.S285134

26. Ebokaiwe AP, Okori S, Nwankwo JO, Ejike CECC, Osawe SO (2021) Selenium nanoparticles and metformin ameliorate streptozotocin-instigated brain oxidative-inflammatory stress and neurobehavioral alterations in rats., Naunyn. Schmiedebergs. Arch Pharmacol 394:591-602. https://doi.org/10.1007/ s00210-020-02000-2

27. Ramesh T (2021) Oxidative stress and hepatocellular mitochondrial dysfunction attenuated by asiatic acid in streptozotocininduced diabetic rats. J King Saud Univ - Sci 33:101369. https:// doi.org/10.1016/j.jksus.2021.101369

28. Baynes JW (1991) Role of oxidative stress in development of complications in diabetes. Diabetes 40:405-412. https://doi.org/ 10.2337/diab.40.4.405

29. Özgümüş T, Sulaieva O, Jessen LE, Jain R, Falhammar H, Nyström T, Catrina S-B, Jörneskog G, Groop L, Eliasson M, Eliasson B, Brismar K, Stokowy T, Nilsson PM, Lyssenko V (2021) Reduced expression of OXPHOS and DNA damage genes is linked to protection from microvascular complications in longterm type 1 diabetes: the PROLONG study. Sci Rep 11:20735. https://doi.org/10.1038/s41598-021-00183-z

30. Islam N, Dmour I, Taha MO (2019) Degradability of chitosan micro/nanoparticles for pulmonary drug delivery. Heliyon 5:e01684. https://doi.org/10.1016/j.heliyon.2019.e01684

31. Estevez H, Garcia-Lidon JC, Luque-Garcia JL, Camara C (2014) Effects of chitosan-stabilized selenium nanoparticles on cell proliferation, apoptosis and cell cycle pattern in HepG2 cells: comparison with other selenospecies. Colloids Surf B Biointerfaces 122:184-193. https://doi.org/10.1016/j.colsurfb.2014.06.062

32. Luo Y, Zhang B, Cheng W-H, Wang Q (2010) Preparation, characterization and evaluation of selenite-loaded chitosan/TPP nanoparticles with or without zein coating. Carbohydr Polym 82:942-951. https://doi.org/10.1016/j.carbpol.2010.06.029

33. Liang H, Ding X, Zhou C, Zhang Y, Xu M, Zhang C, Xu L (2012) Knockdown of eukaryotic translation initiation factors 3B (EIF3B) inhibits proliferation and promotes apoptosis in glioblastoma cells., Neurol. Sci. Off. J. Ital. Neurol. Soc. Ital. Soc. Clin Neurophysiol 33:1057-1062. https://doi.org/10.1007/ s10072-011-0894-8

34. Bai K, Hong B, He J, Hong Z, Tan R (2017) Preparation and antioxidant properties of selenium nanoparticles-loaded chitosan microspheres. Int J Nanomedicine 12:4527-4539. https:// doi.org/10.2147/IJN.S129958

35. Wu Y, Yang W, Wang C, Hu J, Fu S (2005) Chitosan nanoparticles as a novel delivery system for ammonium glycyrrhizinate. Int J Pharm 295:235-245. https://doi.org/10.1016/j.ijpharm. 2005.01.042

36. Robertson RP (2004) Chronic oxidative stress as a central mechanism for glucose toxicity in pancreatic islet beta cells in diabetes. J Biol Chem 279:42351-42354. https://doi.org/10. 1074/jbc.R400019200

37. Patel SB, Santani D, Patel V, Shah M (2015) Anti-diabetic effects of ethanol extract of Bryonia laciniosa seeds and its saponins rich fraction in neonatally streptozotocin-induced diabetic rats. Pharmacognosy Res 7:92-99. https://doi.org/10. 4103/0974-8490.147217

38. Bedoya FJ, Solano F, Lucas M (1996) N-monomethyl-arginine and nicotinamide prevent streptozotocin-induced double strand DNA break formation in pancreatic rat islets. Experientia 52:344-347. https://doi.org/10.1007/BF01919538

39. Elsner M, Guldbakke B, Tiedge M, Munday R, Lenzen S (2000) Relative importance of transport and alkylation for pancreatic beta-cell toxicity of streptozotocin. Diabetologia 43:1528-1533. https://doi.org/10.1007/s001250051564

40. Kim S-H, Park M-J (2017) Effects of growth hormone on glucose metabolism and insulin resistance in human. Ann Pediatr Endocrinol Metab 22:145-152. https://doi.org/10.6065/apem. 2017.22.3.145

41. Rajpathak SN, Gunter MJ, Wylie-Rosett J, Ho GYF, Kaplan RC, Muzumdar R, Rohan TE, Strickler HD (2009) The role of insulin-like growth factor-I and its binding proteins in glucose homeostasis and type 2 diabetes., Diabetes. Metab. Res Rev 25:3-12. https://doi.org/10.1002/dmrr.919

42. Chu Q, Moreland R, Yew NS, Foley J, Ziegler R, Scheule RK (2008) Systemic insulin-like growth factor-1 reverses hypoalgesia and improves mobility in a mouse model of diabetic peripheral neuropathy. Mol Ther 16:1400-1408. https://doi. org/10.1038/mt.2008.115

43. X Zhang, JK Yang, C Chen (2018) Enhanced pulsatile growth hormone secretion and altered metabolic hormones by in vivo hexarelin treatment in streptozotocin-induced diabetic rats., Int J Mol Sci 19 https://doi.org/10.3390/ijms19103067

44 Abdulmalek SA, Balbaa M (2019) Synergistic effect of nanoselenium and metformin on type 2 diabetic rat model: diabetic complications alleviation through insulin sensitivity, oxidative mediators and inflammatory markers. PLoS One 14:e0220779

45. P Vural, G Kabaca, RD Firat, S Degirmecioglu (2017) Administration of selenium decreases lipid peroxidation and increases vascular endothelial growth factor in streptozotocin induced diabetes mellitus. Cell J 19 https://doi.org/10.22074/cellj.2017. 4161

46. Ezaki O (1990) The insulin-like effects of selenate in rat adipocytes. J Biol Chem 265:1124-1128

47 Al-Quraishy S, Dkhil MA, Abdel Moneim AE (2015) Antihyperglycemic activity of selenium nanoparticles in streptozotocin-induced diabetic rats. Int J Nanomedicine 10:6741-6756. https://doi.org/10.2147/IJN.S91377

48. Guo W, Yi L, Zhou B, Li M (2020) Chitosan modifies glycemic levels in people with metabolic syndrome and related disorders: meta-analysis with trial sequential analysis. Nutr J 19:130. https://doi.org/10.1186/s12937-020-00647-4 
49. Romero-Pérez A, García-García E, Zavaleta-Mancera A, Ramírez-Bribiesca JE, Revilla-Vázquez A, Hernández-Calva LM, López-Arellano R, Cruz-Monterrosa RG (2010) Designing and evaluation of sodium selenite nanoparticles in vitro to improve selenium absorption in ruminants. Vet Res Commun 34:71-79. https://doi.org/10.1007/s11259-009-9335-z

50. K Bai, B Hong, J He, W Huang (2020) Antioxidant capacity and hepatoprotective role of chitosan-stabilized selenium nanoparticles in concanavalin A-induced liver injury in mice., Nutrients. 12 https://doi.org/10.3390/nu12030857

51. Mao J, Teng W (2013) The relationship between selenoprotein $\mathrm{P}$ and glucose metabolism in experimental studies. Nutrients 5:1937-1948. https://doi.org/10.3390/nu5061937

52. Campbell SC, Aldibbiat A, Marriott CE, Landy C, Ali T, Ferris WF, Butler CS, Shaw JA, Macfarlane WM (2008) selenium stimulates pancreatic beta-cell gene expression and enhances islet function. FEBS Lett 582:2333-2337. https://doi.org/10. 1016/j.febslet.2008.05.038

53. Maggio M, De Vita F, Lauretani F, Buttò V, Bondi G, Cattabiani C, Nouvenne A, Meschi T, Dall'Aglio E, Ceda GP (2013) IGF1 , the cross road of the nutritional, inflammatory and hormonal pathways to frailty. Nutrients. 5:4184-4205. https://doi.org/10. 3390/nu5104184

54. Serrano-Martín X, Payares G, Mendoza-León A (2006) Glibenclamide, a blocker of $\mathrm{K}+(\mathrm{ATP})$ channels, shows antileishmanial activity in experimental murine cutaneous leishmaniasis. Antimicrob Agents Chemother 50:4214-4216. https://doi.org/10.1128/ AAC.00617-06

55. Li YQ, Zhou FC, Gao F, Bian JS, Shan F (2009) Comparative evaluation of quercetin, isoquercetin and rutin as inhibitors of $\alpha$-glucosidase. J Agric Food Chem 57:11463-11468. https://doi. org/10.1021/jf903083h

56. B. Raman, A. Naga, V.L. Krishna, B.N. Rao, M.V.B. Rao, 2012 Plants with antidiabetic activities and their medicinal values, in

57 Sarmadi B, Aminuddin F, Hamid M, Saari N, Abdul-Hamid A, Ismail A (2012) Hypoglycemic effects of cocoa (Theobroma cacao L.) autolysates. Food Chem 134:905-911. https://doi.org/ 10.1016/j.foodchem.2012.02.202

58. McCue P, Vattem D, Shetty K (2004) Inhibitory effect of clonal oregano extracts against porcine pancreatic amylase in vitro. Asia Pac J Clin Nutr 13:401-408

59. Kalaiarasi P, Kaviarasan K, Pugalendi KV (2009) Hypolipidemic activity of $18 \beta$-glycyrrhetinic acid on streptozotocin-induced diabetic rats. Eur J Pharmacol 612:93-97. https://doi.org/10.1016/j. ejphar.2009.04.003

60. Becker DJ, Reul B, Ozcelikay AT, Buchet JP, Henquin JC, Brichard SM (1996) Oral selenate improves glucose homeostasis and partly reverses abnormal expression of liver glycolytic and gluconeogenic enzymes in diabetic rats. Diabetologia 39:3-11. https:// doi.org/10.1007/BF00400407

61. Kumar GS, Kulkarni A, Khurana A, Kaur J, Tikoo K (2014) Selenium nanoparticles involve HSP-70 and SIRT1 in preventing the progression of type 1 diabetic nephropathy. Chem Biol Interact 223:125-133. https://doi.org/10.1016/j.cbi.2014.09.017

62. Obafemi TO, Akinmoladun AC, Olaleye MT, Agboade SO, Onasanya AA (2017) Antidiabetic potential of methanolic and flavonoid-rich leaf extracts of Synsepalum dulcificum in type 2 diabetic rats. J Ayurveda Integr Med 8:238-246. https://doi.org/ 10.1016/j.jaim.2017.01.008

63. Silvestrini A, Mordente A, Martino G, Bruno C, Vergani E, Meucci E, Mancini A (2020) The role of selenium in oxidative stress and in nonthyroidal illness syndrome (NTIS): an overview. Curr Med Chem 27:423-449. https://doi.org/10.2174/09298 67325666180201111159

64. P. Sutthasupha, A. Lungkaphin, 2020 The potential roles of chitosan oligosaccharide in prevention of kidney injury in obese and diabetic conditions, Food Funct. 11 https://doi.org/10.1039/d0fo0 0302f.

65 Chukwunonso Obi B, Chinwuba Okoye T, Okpashi VE, Nonye Igwe C, Olisah Alumanah E (2016) Comparative study of the antioxidant effects of metformin glibenclamide, and repaglinide in alloxan-induced diabetic rats. J Diabetes Res 2016:1635361. https://doi.org/10.1155/2016/1635361

66 Abdulkadir AAA, Thanoon IA-J (2012) Comparative effects of glibenclamide and metformin on C-reactive protein and oxidant/antioxidant status in patients with type II diabetes mellitus. Sultan Qaboos Univ Med J 12:55-61. https://doi.org/10.12816/ 0003088

67. Hazlehurst JM, Woods C, Marjot T, Cobbold JF, Tomlinson JW (2016) Non-alcoholic fatty liver disease and diabetes. Metabolism 65:1096-1108. https://doi.org/10.1016/j.metabol.2016.01. 001

68. Mertens J, De Block C, Spinhoven M, Driessen A, Francque SM, Kwanten WJ (2021) Hepatopathy associated with type 1 diabetes: distinguishing non-alcoholic fatty liver disease from glycogenic hepatopathy. Front Pharmacol 12:2921. https://doi. org/10.3389/fphar.2021.768576

69. Ghimire S, Shakya S, Shakya J, Acharya P, Pardhe BD (2018) Abnormal Liver parameters among individuals with type 2 diabetes mellitus Nepalese Population. Biochem Pharmacol 7:1-5

70. Wang Y-Y, Qiu W-Y, Sun L, Ding Z-C, Yan J-K (2018) Preparation, characterization, and antioxidant capacities of selenium nanoparticles stabilized using polysaccharide-protein complexes from Corbicula fluminea. Food Biosci 26:177-184. https://doi. org/10.1016/j.fbio.2018.10.014

71. Long L, Qiu H, Cai B, Chen N, Lu X, Zheng S, Ye X, Li Y (2018) Hyperglycemia induced testicular damage in type 2 diabetes mellitus rats exhibiting microcirculation impairments associated with vascular endothelial growth factor decreased via PI3K/ Akt pathway. Oncotarget 9:5321-5336. https://doi.org/10.18632/ oncotarget.23915

72. Abdul-Ghani MA, Jayyousi A, DeFronzo RA, Asaad N, AlSuwaidi J (2019) Insulin resistance the link between T2DM and CVD: basic mechanisms and clinical implications. Curr Vasc Pharmacol 17:153-163. https://doi.org/10.2174/1570161115 666171010115119

73. Huynh K, Bernardo BC, McMullen JR, Ritchie RH (2014) Diabetic cardiomyopathy: mechanisms and new treatment strategies targeting antioxidant signaling pathways. Pharmacol Ther 142:375-415. https://doi.org/10.1016/j.pharmthera.2014.01.003

74. Wiviott SD, Cannon CP, Morrow DA, Murphy SA, Gibson CM, McCabe CH, Sabatine MS, Rifai N, Giugliano RP, DiBattiste PM, Demopoulos LA, Antman EM, Braunwald E (2004) Differential expression of cardiac biomarkers by gender in patients with unstable angina/non-ST-elevation myocardial infarction: a TACTICS-TIMI 18 (Treat Angina with Aggrastat and determine Cost of Therapy with an Invasive or Conservative StrategyThromb. Circulation 109:580-586. https://doi.org/10.1161/01. CIR.0000109491.66226.26

75. Huang E-J, Kuo W-W, Chen Y-J, Chen T-H, Chang M-H, Lu M-C, Tzang B-S, Hsu H-H, Huang C-Y, Lee S-D (2006) Homocysteine and other biochemical parameters in Type 2 diabetes mellitus with different diabetic duration or diabetic retinopathy. Clin Chim Acta 366:293-298. https://doi.org/10.1016/j.cca.2005. 10.025

76. Xu T, Liu Y, Deng Y, Meng J, Li P, Xu X, Zeng J (2016) [Insulin combined with selenium inhibit p38MAPK/CBP pathway and suppresses cardiomyocyte apoptosis in rats with diabetic cardiomyopathy]., Xi bao yu fen zi mian yi xue za zhi $=$ Chinese. $\mathrm{J}$ Cell Mol Immunol 32:926-930

77. Bilginoglu A, Seymen A, Tuncay E, Zeydanli E, AydemirKoksoy A, Turan B (2009) Antioxidants but not doxycycline 
treatments restore depressed beta-adrenergic responses of the heart in diabetic rats. Cardiovasc Toxicol 9(21):9

78. Dhanya BL, Swathy RP, Indira M (2014) Selenium downregulates oxidative stress-induced activation of leukotriene pathway in experimental rats with diabetic cardiac hypertrophy. Biol Trace Elem Res 161(107):15. https://doi.org/10.1007/ s12011-014-0076-7

79 Lee TM, Chou TF (2003) Impairment of myocardial protection in type 2 diabetic patients. J Clin Endocrinol Metab 88(531):7. https://doi.org/10.1210/jc.2002-020904

80 Abrahamson MJ (2015) Should sulfonylureas remain an acceptable first-Line add-On to metformin therapy in patients with type 2 diabetes? Yes, they continue to serve us well! Diabetes Care 38(166):9. https://doi.org/10.2337/dc14-1945

81. Kulkarni CR, Joglekar MM, Patil SB, Arvindekar AU (2012) Antihyperglycemic and antihyperlipidemic effect of Santalum album in streptozotocin induced diabetic rats. Pharm Biol 50:360-365. https://doi.org/10.3109/13880209.2011.604677

82. Ramachandran B, Ravi K, Narayanan V, Kandaswamy M, Subramanian S (2004) Protective effect of macrocyclic binuclear oxovanadium complex on oxidative stress in pancreas of streptozotocin induced diabetic rats. Chem Biol Interact 149:9-21. https://doi.org/10.1016/j.cbi.2004.06.007

83. Li Z, Yang R, Xu G, Xia T (2005) Serum lipid concentrations and prevalence of dyslipidemia in a large professional population in Beijing. Clin Chem 51:144-150. https://doi.org/10. 1373/clinchem.2004.038646

84. Camont L, Chapman MJ, Kontush A (2011) Biological activities of HDL subpopulations and their relevance to cardiovascular disease. Trends Mol Med 17:594-603. https://doi.org/10. 1016/j.molmed.2011.05.013

85. Jiang C, Wang Q, Wei Y, Yao N, Wu Z, Ma Y, Lin Z, Zhao M, Che C, Yao X, Zhang J, Yin Z (2015) Cholesterol-lowering effects and potential mechanisms of different polar extracts from Cyclocarya paliurus leave in hyperlipidemic mice. J Ethnopharmacol 176:17-26. https://doi.org/10.1016/j.jep.2015.10.006

86. Schinner S (2009) Wnt-signalling and the metabolic syndrome. Horm Metab Res 41(159):63. https://doi.org/10.1055/s-00281119408

87. Song K, Wang S, Mani M, Mani A (2014) Wnt signaling, de novo lipogenesis adipogenesis and ectopic fat. Oncotarget 5:11000-11003

88. Wu JHY, Lemaitre RN, Manichaikul A, Guan W, Tanaka T, Foy M, Kabagambe EK, Djousse L, Siscovick D, Fretts AM, Johnson C, King IB, Psaty BM, McKnight B, Rich SS, Chen Y-DI, Nettleton JA, Tang W, Bandinelli S, Jacobs DRJ, Browning BL, Laurie CC, Gu X, Tsai MY, Steffen LM, Ferrucci L, Fornage M, Mozaffarian D (2013) Genome-wide association study identifies novel loci associated with concentrations of four plasma phospholipid fatty acids in the de novo lipogenesis pathway: results from the Cohorts for Heart and Aging Research in Genomic Epidemiology (CHARGE) consorti. Circ Cardiovasc Genet 6:171-183. https:// doi.org/10.1161/CIRCGENETICS.112.964619

89. Smith U (2007) TCF7L2 and type 2 diabetes-we WNT to know. Diabetologia 50:5-7. https://doi.org/10.1007/s00125-006-0521-z

90. Cauchi S, Meyre D, Dina C, Choquet H, Samson C, Gallina S, Balkau B, Charpentier G, Pattou F, Stetsyuk V, Scharfmann R, Staels B, Frühbeck G, Froguel P (2006) Transcription factor TCF7L2 genetic study in the French population: expression in human beta-cells and adipose tissue and strong association with type 2 diabetes. Diabetes 55:2903-2908. https://doi.org/10.2337/ db06-0474

91. Pearson ER, Donnelly LA, Kimber C, Whitley A, Doney ASF, McCarthy MI, Hattersley AT, Morris AD, Palmer CNA (2007)
Variation in TCF7L2 influences therapeutic response to sulfonylureas: a GoDARTs study. Diabetes 56:2178-2182. https://doi. org/10.2337/db07-0440

92 Savic D, Ye H, Aneas I, Park SY, Bell GI, Nobrega MA (2011) Alterations in TCF7L2 expression define its role as a key regulator of glucose metabolism. Genome Res 21(1417):25. https://doi. org/10.1101/gr.123745.111

93. Ezzidi I, Turki A, Messaoudi S, Chaieb M, Kacem M, Al-Khateeb GM, Mahjoub T, Almawi WY, Mtiraoui N (2010) Common polymorphisms of calpain-10 and the risk of type 2 diabetes in a Tunisian Arab population: a case-control study. BMC Med Genet 11:75. https://doi.org/10.1186/1471-2350-11-75

94. Hatta T, Iemura S, Ohishi T, Nakayama H, Seimiya H, Yasuda T, Iizuka K, Fukuda M, Takeda J, Natsume T, Horikawa Y (2018) Calpain-10 regulates actin dynamics by proteolysis of microtubule-associated protein 1B. Sci Rep 8:16756. https://doi.org/10. 1038/s41598-018-35204-X

95. Wang T, Gao Y, Wang X, Shi Y, Xu J, Wu B, He J, Li Y (2019) Calpain-10 drives podocyte apoptosis and renal injury in diabetic nephropathy. Diabetes Metab Syndr Obes 12:1811-1820. https:// doi.org/10.2147/DMSO.S217924

96. Smith MA, Schnellmann RG (2012) Calpains, mitochondria, and apoptosis. Cardiovasc Res 96:32-37. https://doi.org/10.1093/cvr/ cvs163

97. Chen B, Zhao Q, Ni R, Tang F, Shan L, Cepinskas I, Cepinskas G, Wang W, Schiller PW, Peng T (2014) Inhibition of calpain reduces oxidative stress and attenuates endothelial dysfunction in diabetes. Cardiovasc Diabetol 13:88. https://doi.org/10.1186/ 1475-2840-13-88

98. Yan S-T, Li C-L, Tian H, Li J, Pei Y, Liu Y, Gong Y-P, Fang F-S, Sun B-R (2014) Association of calpain-10 rs2975760 polymorphism with type 2 diabetes mellitus: a meta-analysis. Int J Clin Exp Med 7:3800-3807

99. Madhu S, Sinha B, Aslam M, Mehrotra G, Dwivedi S (2017) Postprandial triglyceride responses and endothelial function in prediabetic first-degree relatives of patients with diabetes. J Clin Lipidol 11:1415-1420. https://doi.org/10.1016/j.jacl.2017.08.001

100 Mukherjee AA, Kandhare AD, Bodhankar SL (2017) Elucidation of protective efficacy of Pentahydroxy flavone isolated from Madhuca indica against arsenite-induced cardiomyopathy: Role of Nrf-2, PPAR- $\gamma$, c-fos and c-jun. Environ Toxicol Pharmacol 56:172-185. https://doi.org/10.1016/j.etap.2017.08.027

101 Freitag CM, Miller RJ (2014) Peroxisome proliferator-activated receptor agonists modulate neuropathic pain: a link to chemokines? Front Cell Neurosci 8(172):185. https://doi.org/ 10.3389/fncel.2014.00238

102. Lee KW, Ku YH, Kim M, Ahn BY, Chung SS, Park KS (2011) Effects of sulfonylureas on peroxisome proliferator-activated receptor $\gamma$ activity and on glucose uptake by thiazolidinediones. Diabetes Metab J 35:340-347. https://doi.org/10.4093/dmj.2011. 35.4.340

103. Pisarev VB, Snigur GL, Spasov AA, Samokhina MP, Bulanov AE (2009) Mechanisms of toxic effect of streptozotocin on $\beta$-cells in the islets of Langerhans. Bull Exp Biol Med 148:937939. https://doi.org/10.1007/s10517-010-0856-9

104. Wang L, Li C, Huang Q, Fu X (2019) Biofunctionalization of selenium nanoparticles with a polysaccharide from Rosa roxburghii fruit and their protective effect against $\mathrm{H} 2 \mathrm{O} 2$-induced apoptosis in INS-1 cells. Food Funct 10:539-553. https://doi. org/10.1039/C8FO01958D

Publisher's Note Springer Nature remains neutral with regard to jurisdictional claims in published maps and institutional affiliations. 